\title{
Study on Quality Parameters and Storage Stability of Mango Coated with Developed Nanocomposite Edible Film
}

\author{
Praveen Kumar Dubey ${ }^{1}$, Rama Nath Shukla ${ }^{1}$, Gaurav Srivastava ${ }^{2}$, \\ Atul Anand Mishra ${ }^{1}$ and Ashutosh Pandey ${ }^{1}$
}

${ }^{1}$ Department of Food Process Engineering, Vaugh Institute of Agriculture Engineering and Technology, Sam Higginbottom University of Agriculture, Technology and Sciences, SHUATS

University P.O Naini, Allahabad, U.P-211007, India

${ }^{2}$ Department of Biotechnology, Institute of Engineering and technology, Bundelkhand

University, Jhansi, U.P-284128, India

*Corresponding author

\section{A B S T R A C T}

\begin{tabular}{|l|}
\hline K e y w o r d s \\
$\begin{array}{l}\text { Mangifera indica L., } \\
\text { Nanocomposite edible } \\
\text { film, edible coating, } \\
\text { glycerol, Nanoparticles } \\
\text { solution }\end{array}$ \\
\hline Article Info \\
\hline $\begin{array}{l}\text { Accepted: } \\
\text { 20 March } 2019 \\
\text { Available Online: } \\
10 \text { April } 2019\end{array}$ \\
\hline \hline
\end{tabular}

Keywords

\section{Introduction}

India is a cultivar of varieties of fruits, where Mango is grown almost in all the states of India. Uttar Pradesh tops the list of mango producing states. Other major producing states are Andhra Pradesh, Maharashtra, Karnataka, Bihar and Gujarat. Rest of the states has quite less production.

These days, people are more conscious about their health and are aware of the importance of including fruits in their diet. Fruits are an important part of a healthy diet. Fresh fruit help to cleanse the body and easy to digest. Fresh fruits are more healthier than processed any kind of juice. Because processed juice is just as unhealthy as a sugary drink.

Usually processing juice methods, it removes the flavor and by adding preservatives, which are not good for health. Fruit juice contains no fiber and is very high in sugar. That is the one of reason for gaining weight in children. But 
$100 \%$ Fruit juice (concentrated form) contains some nutrients and healthy.

Dasheri mangoes are considered "table" mangoes, meaning they are most often eaten fresh, out of hand. Slice both halves away from the stone, and slice the mango horizontally and vertically while still adhered to the skin. Carefully slice away the skin from the diced mango and add to fruit salads or smoothies. The sweetness and flavor of Dasheri mangoes makes them ideal for fresh and dessert applications. One Dasheri grower suggests taking a ripe Dasheri mango in hand, squeezing the fruit to soften the pulp and poking a hole in the skin to release the juice. Dasheri mangoes keep well; they take around 6 days to ripen at room temperature, and can be refrigerated for up to a week afterwards.

In Mango various biochemical changes during the ripening process affect its composition and quality. Soft texture of mango fruit limits the postharvest life and increase susceptibility to various pathogenic infections. Several techniques have been used to reduce deterioration, extend the shelf life and maintain quality of mango fruit, including low temperature, controlled or modified atmosphere storage, hypobaric storage, chemicals, irradiation and coatings. Refrigeration storage has been shown to be an effective method to maintain postharvest quality and extend the shelf life of mango fruit Mitra and Baldwin, (1997). However, mango fruit are susceptible to chilling injury, when stored below $13^{\circ} \mathrm{C}$ Nair and Singh, (2003). Controlled atmosphere reduced physicochemical changes and delayed the ripening process of mango fruit Rao and Rao, (2008), but can cause poor colour, undesirable flavour and physiological disorders Thompson, (2001). Continuous use of fungicides has been used to reduce postharvest decay and extend the shelf life of fruit. However, fungicide resistance by pathogens, consumer concerns about the residue of fungicides on the fruit surface and its impact on the environment, has needed the development of consumers and environment friendly bio preservative Charles et al., 1994; Mari et al., (2014). Natural products are useful and taking place as an alternative approaches for delaying ripening and reducing postharvest deterioration of fruit Tripathi and Dubey (2004).

Nanotechnology in these days has quickly emerged as one of the most promising and attractive research fields in food industry. Nanoemulsions and nanoparticles may contribute to barrier properties and functionality of coatings for fruit preservation since these systems show an increased surface area. The high surface area to volume ratio of nanoparticles provides a tremendous driving force for diffusion, especially at elevated temperatures.

The term "nanoparticle" is not usually applied to individual molecules; it usually refers to inorganic materials. Suspensions of nanoparticles are possible since the interaction of the particle surface with the solvent is strong enough to overcome density differences, which otherwise usually result in a material either sinking or floating in a liquid. Zinc oxide $(\mathrm{ZnO})$ nano powders are available as powders and dispersions. These nanoparticles exhibit antibacterial, anticorrosive, antifungal and UV filtering properties. Zinc is a Block D, Period 4 element while Oxygen is a Block P, Period 2 element. Some of the synonyms of zinc oxide nanoparticles are oxydatum, zincioxicum, permanent white, ketozinc and oxozin. So, we have to use that material $(\mathrm{ZnO})$ which is antibacterial, antifungicidal and also controlling ethylene excessive production through breaking of ethylene. Therefore Nanoparticles which are used to giving small amount (nano amount) of chemical which mix with glycerol and polymer (Aloe vera) and 
coating on the surface of Mango. Due to their fewer amounts it is not be harmful to our body so, we take $\mathrm{ZnO}$ (metal oxide).

Edible films can also be used to preserve fruits and vegetables; they are formed separately as sheets or also are formed by moulding them into desired shape and then are used as primary or secondary packaging materials. The formation of edible films consists of two main steps, casting of the film forming solution followed by drying at different temperatures depending upon the raw materials used for film making. When compared to other food packaging materials like glass, synthetic plastics, cans etc the most important advantage of biodegradable edible films is the easy availability of plenty of bio based raw materials which can be blended to form appropriate packaging design according to the specific need of each food to be packed Lopez et al., (2004).

In some years before, there is an increasing interest in the use of A. vera gel as a source of functional ingredients in drinks, ice creams and beverages as well as being applied as an edible coating Martinez et al., (2006). Aloe vera gel has many medicinal values and has the ability to inhibit the growth of both gram negative and gram positive bacteria, its composition makes it a natural antimicrobial agent (Habeeb et al., 2007). The aloe vera gel consists of a component called Anthraquinone which retards the growth of Staphylococcus aureus strains and Escherichia coli, by inhibiting the mechanism of solute transport in their membranes Hamman et al., (2008), Lone et al., (2009).

The film forming solution of an edible film must consist of a natural polymer which is capable of forming a stable and amorphous three dimensional structure, the functional properties of the final film depends on the the structural heterogeneity, thermal sensitivity, and hydrophilic behaviour of such polymer. These natural biodgradable polymers are extracted from plants and animals, they include corn zein, wheat gluten, soy protein, collagen and gelatin, casein and caseinates, and whey proteins, Malhotra et al.,(2015), Biscarat et al.,(2015), Arrieta et al.,(2014).

Now another important component of an edible film is the plasticizer, it helps to overcome the brittleness of the film and increases its flexibility, workability and dispensability. In this study glycerol was used as the plasticizer, glycerol is a thick liquid having a sweet taste, it is transparent and odourless. It is obtained from petrochemical or natural sources or else is also produced by fermentation of sugar (Chang et al., 2000; Karbowiak et al., 2006).

In recent years many studies have been conducted with the aim of combining such bio materials to preserve perishable food products and also to reduce the accumulation of plastic wastes. This is done by taking the advantage of compatibility between the molecules of the bio materials used for the film production. The mechanical and barrier properties of these films not only depend on the compounds used in the polymer matrix, but also on their compatibility (Altenhofen et al., 2009).

\section{Materials and Methods}

The dissertation work on "Study on quality parameters and storage stability of Mango coated with developed nanocomposite edible film" is conducted at the Food Processing Laboratories of the Department of Food Process Engineering, Vaugh Institute of Agricultural Engineering and Technology, Sam Higginbottom University of Agriculture Technology and Sciences, Allahabad. The details of materials and methods used during the course of the present project are as follows: 


\section{Materials Required}

The materials required for the development of film and coatings were $\mathrm{ZnO}$ nanoparticle, aloe vera gel, and glycerol. Fresh and firm mangoes were procured from the agriculture farms of Malihabad, Lucknow. Bright colored Mangoes with almost uniform size and shape, free from blemishes, apparent diseases, and injuries, were selected for coating.

\section{Aloe vera Gel}

Aloe vera plants are known for their medicinal properties. When incorporated into edible films and coatings, it has proved to show delay of deterioration of fruits and vegetables and have saved them from post-harvest decay. Aloe vera gel has natural antibacterial and antifungal components and thus its capable of preventing many food borne diseases.

The gel obtained from aloe vera is odourless, colourless and slightly bitter and has film/coating forming ability when incorporated with other gelling agents or plasticizers.

They are a good alternative to synthetic preservation of fruits and vegetables as they are environment friendly and safe for consumption.

The aloe vera plant has mainly two layers, the outer layer is a bit thick with thorns on both sides of the leaf, generally known as the rind portion, leaf has another section inside which is soft and fleshy, this section is known as its gel.

Aloe vera gel is also rich in many useful components, The chemical analysis of the aloe vera plant was believed to be first done by Rowe, (1940) who found that aloe vera contained about 75 nutrients and 200 active components such as sugar, anthraquinones, saponins, vitamins, enzymes, minerals, lignin, salicylic acid and amino acids.

\section{ZnO Nanoparticles}

$\mathrm{ZnO}$ is nontoxic and compatible with human skin by creating an acceptable additive for textiles and surfaces that are in contact with flesh. In comparison to bulk, the rising extent of nanoscale $\mathrm{ZnO}$ has the potential to enhance the potency of fabric operation. As a vital semiconductor with tremendous scientific and technological interest, $\mathrm{ZnO}$ has an outsized exciton-binding energy $(60 \mathrm{meV})$ Huang et al., (2001) and on the spot wide gap (3.37 eV) that could be the most well-liked multitasking metal and chemical compound which contains an enormous list of enticing properties. As a result of its distinctive optical and electrical properties Vayssieres et al., (2001) it is considered to be a possible material in optoelectronic applications to operate in the visible and close to ultraviolet spectral regions. ZnO-NPs are widely utilized in several industrial areas such as UV lightemitting devices Rajalakshmi et al., (2012), ethanol gas sensors, photo-catalysts, pharmaceutical, and cosmetic industries.

Properties including non-toxic, self-cleansing, compatible with skin, antimicrobial, and dermatologic associate degreed are employed as UV-blocker in sunscreens and lots of medical specialty applications. $\mathrm{ZnO}$ seems to powerfully resist microorganisms, while several reports show sizeable antibacterial drug activities of $\mathrm{CaO}, \mathrm{MgO}$ and $\mathrm{ZnO}$ that is attributed to the generation of Reactive Oxygen Species (ROS) on the surface of these oxides. In spite of those deserves, $\mathrm{ZnO}$ is biosafe, biocompatible with distinctive abilities such as structure-dependent, electrical and thermal transport properties, that might vary according to the particle size, shape, morphology, orientation and ratio by Mirzaeia and Darroudi (2017). 


\section{Glycerol}

Glycerol is a transparent, odourless and a thick liquid it has a sweet taste and is obtained from bio based materials followed by purification before its sale. In the food packaging world glycerol is usually used as plasticizer, it is because the molecule is highly hydrophilic and when added with water mixes into the solution very well. Glycerol is also easily available and is abundant and cheap. Elongation of edible films generally increases with increasing concentration of glycerol, as glycerol addition plasticizes the film or makes the films more flexible. Glycerol when added into a protein based solution such as nanoparticles reduces the intermolecular forces between them and makes the films more elastic.

Glycerol addition to a film forming solution also increases the mobility of the biopolymer chains and also helps in relaxing the strength between $\mathrm{H}-\mathrm{H}$ bonds and hence disperses itself well into the solution to which it was added. As glycerol addition bring a lot of changes in the molecular organization of bio materials used for film or coating preparation, it improves the functional properties of films and coatings by improving extensibility, dispensability, and flexibility and by reducing cohesion, elasticity, mechanical properties, and rigidity. The most used food-grade plasticizers are glycerol and sorbitol Swain $e t$ al., (2004).

\section{Equipments used}

Most of the equipments used in the experiment were available in the Food Tech.

Lab, Department of Food Process Engineering, Vaugh Institute of Agricultural Engineering and Technology, Sam Higginbottom University of Agriculture Technology and Sciences, Allahabad. Mechanical testing of the developed film was done using Universal testing machine in the Department of Material science and technology at Banaras Hindu University (BHU), Varanasi.

\section{Development of composite edible films}

The following are the flow charts and procedure which depicts the methodology for the development of composite edible films.

\section{Procedure for development of composite edible films}

Fresh aloe vera gel was obtained by filtration method. The extracted gel was then pasteurized at $50^{\circ} \mathrm{C}$ for $15 \mathrm{~min}$ to reduce the enzymatic activity, then it was subjected to stabilization process by addition of ascorbic acid $(2.0 \mathrm{~g} / \mathrm{l})$ and citric acid $(4.5 \mathrm{~g} / \mathrm{l})$ to prevent oxidation of the gel.

The standard solution $(100 \mathrm{ml})$ for the film was prepared using $90 \mathrm{ml}$ of aloe vera gel and $10 \mathrm{ml}$ of distilled water with $\mathrm{ZnO}$ nanoparticles. Different concentration of Aloe vera $(90 \%$, $80 \%$ and $70 \%$ ) was first hydrated into $100 \mathrm{ml}$ of standard solution at room temperature, and was later solubilized at $50^{\circ} \mathrm{C}$ followed by glycerol addition $(1 \mathrm{~g}, 2 \mathrm{~g}, 3 \mathrm{~g})$.

The solution was then slowly agitated till the mixing of all the ingredients.

Thus the film forming solution formed was then poured slowly on to a sprayed on fruits and allowed to air dry at room temperature. The edible films were then obtained on the fruits and the next day by packaged it with LDPE.

\section{Edible coating of mango}

The following flow charts depict the methodology for the coating of Mangoes with the film forming solution. 


\section{Procedure for coating of mango}

After selecting the Mango fruits of uniform size and ripeness, they were then cleaned by washing with distilled water for 1 minute followed by air drying at room temperature.

Fruits were coated with the film forming solution (same formulation used for the development of edible films) by spraying them for 1 minute. These coated fruits were then air dried, packaged in LDPE and stored for 9 days at room temperature. Control fruits were also stored for 9 days under same conditions and the quality parameters of all the coated and uncoated samples were evaluated during the storage.

\section{Evaluation of the edible films}

The following properties of the developed composite edible films were then evaluated.

\section{Film thickness}

Film thickness was measured using a screw gauge. Efforts were made to develop all films with uniform thickness by casting the same volume of film forming solution for all the samples, however, there were still variations in the thickness of the final film. Thickness was measured at three different points and the final reading was taken as the mean of all three readings.

\section{Percentage transparency}

For determining the transparency, the developed edible films were cut into thin strips of size $0.5 \times 4 \mathrm{~cm}$, determination was carried out using a spectrophotometer. The instrument was first calibrated using distill water as blank, the mode of the instrument was changed to determine percentage transparency, and the wavelength was set to $600 \mathrm{~nm}$. The cut strips of films were inserted into the cuvette and the readings were noted down one after the other.

\section{Mechanical properties of composite edible films}

Tensile strength and percentage elongation of the films was evaluated using Universal Testing Machine (UTM), model Instron 3369, USA at a ramp rate of $2.00 \mathrm{~mm} / \mathrm{min}$. Film strips from each sample $(10 \mathrm{~cm} \mathrm{X} 2 \mathrm{~cm})$ were cut and mounted between the grips of the equipment tensile strength and percentage elongation was calculated using the following formula.

\section{Calculation}

Tensile strength $=\mathrm{F} /(\mathrm{w})(\mathrm{t})[\mathrm{MPa}] \ldots \ldots$...Eq. (3.1)

Where,

$\mathrm{F}-$ Force $(\mathrm{N})$

$\mathrm{t}-$ Film thickness $(\mathrm{mm})$

w- Width of the film (mm)

$\%$ Elongation $=\mathrm{L}_{\mathrm{f}} / \mathrm{L}_{0} \mathrm{X} 100 \ldots \ldots$...

Where,

$\mathrm{L}_{\mathrm{f}^{-}}$Final length after extension Original length of the film

$\mathrm{L}_{\mathrm{o}}$ - Original length of the film

\section{Sealability}

For determining the sealability of the edible films 2 sample films of size $5 \mathrm{~cm}$ square from each film were cut and were merged in the form of a pouch by sealing. The pouch open ends to be sealed were kept on the lower bar of the instrument, the temperature was adjusted using the knob and then the upper movable bar was pressed against the lower 
one till the beep (alarm) sound was heard. Sealability of the films varied according to the composition.

\section{Analysis of quality parameters of Mango}

The following quality parameters of coated and control Mangoes were analyzed during the storage period.

\section{Percentage weight loss}

For determining the percentage weight loss, Mangoes were weighed after imposing the treatment which served as the initial weight.

The loss in weight was recorded at regular interval at every $3^{\text {rd }}, 6^{\text {th }}$ and $9^{\text {th }}$ day, which served as the final weight. It was determined by the following formula and expressed as percentage.

Wt loss $(\%)=\left(\frac{A-B}{A}\right) * 100 \ldots .$. Eq. $(3.3)$

Where,

A - Original weight $(\mathrm{g})$

B - Final weight in the day of observation $(\mathrm{g})$

\section{Percentage total acidity}

Standardization of 0.1 N Sodium hydroxide solution

For titrable acidity $0.1 \mathrm{~N}$ sodium hydroxide solution was first made by adding $4 \mathrm{~g}$ of $\mathrm{NaOH}$ pellet in 1 liter of distilled water. $10 \mathrm{ml}$ of 0.1 $\mathrm{N}$ hydrochloric acid was taken into a flask along with $50 \mathrm{ml}$ of distill water, to this 3 drops of phenolphthalein indicator was added.

This solution was titrated against $0.1 \mathrm{~N} \mathrm{NaOH}$ solution to get an end point of lemon yellow colour which stayed constant and the titre value were recorded (AOAC 2000).

\section{Titration}

The fruit sample was ground well to get an uniform mixture. $10 \mathrm{~g}$ of this mixture was taken for estimation and was added into 250 $\mathrm{ml}$ of distilled water. This mixture was boiled for about 10 minutes, then removed from the heat source. Immediately $1 \mathrm{ml}$ of phenolphthalein indicator was added and titrated against $0.1 \mathrm{~N} \mathrm{NaOH}$ solution. The end point obtained was faint pink colour with a minimum persistence of $15 \mathrm{sec}$.

\section{Calculation}

Normality of Sodium Hydroxide solution = $\mathrm{V} 1 \times \mathrm{N} / \mathrm{V} 2$......Eq. (3.4)

Where,

V1 $=$ Volume of hydrochloric acid

$\mathrm{N}=$ Normality of hydrochloric acid

V2 = Volume of sodium hydroxide used

Percentage total acidity $(\%)=\mathrm{T}^{\times \mathrm{N}} \times \mathbf{V} \times \mathbf{E} /$ $\mathrm{v}^{\mathrm{XW}} \times 1000 \ldots$. Eq. (3.5)

Where,

$\mathrm{T}=$ Titre value

$\mathrm{N}=$ Normality of $\mathrm{NaOH}$

$\mathrm{V}=$ Volume made up

$\mathrm{E}=$ Equivalent weight of acid

$\mathrm{v}=$ volume of the sample taken for estimation

$\mathrm{W}=$ Weight of the sample taken

\section{Ascorbic acid content}

Fresh Mangoes were selected and sanitized, after the application of coating the ascorbic acid content of the fruits were examined at every $3^{\text {rd }}, 6^{\text {th }}$ and $9^{\text {th }}$ day of storage.

The ascorbic acid content was determined using 2, 6-dichloro- phenol indophenol visual titration method (AOAC 2000). 


\section{Preparation of 3\% metaphosphoric acid}

$30 \mathrm{~g}$ of metaphosphoric acid sticks were weighed and dissolved in $1000 \mathrm{ml}$ of distilled water to prepare $3 \%$ of metaphosphoric acid.

\section{Standard Ascorbic acid solution}

$100 \mathrm{mg}$ of L-ascorbic acid was taken into the 3\% metaphosphoric acid solution made earlier, and the volume was made upto $100 \mathrm{ml}$ with $3 \%$ metaphosphoric acid. $10 \mathrm{ml}$ of this solution was taken and was further diluted to $100 \mathrm{ml}$ with $3 \%$ metaphosphoric acid solution.

\section{Preparation of dye solution}

$42 \mathrm{mg}$ of sodium bicarbonate was measured and added to $150 \mathrm{ml}$ of distilled water, this solution was heated and when it was about to boil, sodium salt of 2, 6-dichloro- phenol indophenol was added. This solution had a dark blue colour; it was allowed to cool at room temperature. After cooling the dye solution was further diluted with distilled water by making the volume upto $200 \mathrm{ml}$. the dye solution was then stored in a brown glass bottle in the refrigerator for further use.

\section{Standardization of dye}

$5 \mathrm{ml}$ of standard ascorbic acid prepared was added with $5 \mathrm{ml}$ of $3 \%$ metaphosphoric acid solution. This mixture was then titrated against the 2, 6-dichloro- phenol indophenol dye solution to get an end point of pink colour which persisted for $15 \mathrm{sec}$.

\section{Calculation,}

Dye factor $=$ ascorbic acid volume $(\mathrm{ml}) / \mathrm{ml}$ of dye.......Eq. (3.6)

\section{Sample preparation}

Fresh Mango fruits were selected, coating was removed and was ground well by adding 3\%
Meta phosphoric acid to obtain an uniform paste. $10 \mathrm{~g}$ of the sample was then taken and volume was made upto $100 \mathrm{ml}$ with $3 \%$ Meta phosphoric acid. This solution was then filtered to obtain a clear extract. $2-10 \mathrm{ml}$ of this extract was then titrated against the dye solution to obtain a pink end point which persisted for at least $15 \mathrm{sec}$.

\section{Calculation}

Ascorbic acid $(\mathrm{mg} / 100 \mathrm{~g})=\mathrm{T}^{\times \mathbf{D}} \times \mathbf{V} \times \mathbf{1 0 0} /$ $\mathrm{A}^{\times \mathrm{W}}$.......Eq. (3.7)

Where,

$\mathrm{T}=$ Titre value

$\mathrm{D}=$ Dye factor

$\mathrm{V}=$ Volume made up

$\mathrm{A}=$ Aliquote of extract taken for estimation

$\mathrm{W}=$ Weight of the sample taken for estimation

\section{Total soluble solids}

TSS was determined using a digital refractometer of 0-32 brix range.

TSS of the coated fruits were determined at every $3^{\text {rd }}, 6^{\text {th }}$ and $9^{\text {th }}$ day.

The instrument was first calibrated using drops of distill water and then were cleaned using a tissue. First the coating of the fruits were removed and they were cut into wedges, then these wedge shaped pieces were given small cuts with the help of a knife to squeeze and extract the fresh juice.

Drops of juice were put on the instrument surface and the readings were taken using the natural light source. 


\section{pH of the fruits}

$\mathrm{pH}$ was determined using a digital $\mathrm{pH}$ meter. The $\mathrm{pH}$ of the fruits was checked at every $3^{\text {rd }}$, $6^{\text {th }}$ and $9^{\text {th }}$ of storage. The coatings were removed and the fruits were groung to a smooth paste in a blender. About $20 \mathrm{ml}$ of this paste was used for the determination, the instrument consists of a reference electrode and a glass electrode, these electrodes were dipped into the sample after calibrating the instrument with solutions of known $\mathrm{pH}$ and the readings were noted down.

\section{Statistical analysis}

The statistical analysis tool used was 'Analysis of variance- two way classification' and 'Analysis of variance- one way classification'. This technique was developed by Dr. R. A. Fisher in 1923 gives an appropriate method capable of analyzing the variation of population variance. The simplest type of lay out is that in which treatments are allotted to the units entirely by chance. To analyze the data, the observations are arranged according to treatments in the form of one way/two way classification. The significant effect of treatment was judged with the help of ' $F$ ' (variance ratio). Calculated $F$ value was compared with the table value of $\mathrm{F}$ at $5 \%$ level of significance. If calculated value exceeded the table value the affect was considered to the significant. The significance of the study was tested at $5 \%$ level.

Where,

$\mathrm{R}=$ Number of Replication

$\mathrm{T}=$ Number of Treatment

d.f $=$ degree of freedom

$\mathrm{CD}=$ Critical difference

MESS $=$ Error mean sum of square.

$\mathrm{TrSS}=$ treatment sum of square

TSS $=$ total sum of square

ErSS $=$ Error sum of square

\section{Results and Discussion}

\section{Results}

The research work on "Study on quality parameters and storage stability of Mango coated with developed nanocomposite edible film" was conducted in the laboratory of the Department of Food Process Engineering, Vaugh Institute of Agricultural Engineering and Technology at Sam Higginbottom University of Agriculture Science and Technology, Allahabad, during Jan-June 2018.

\section{Development of composite edible films}

The research work involved development of composite edible films based on aloe vera gel, nanoparticles solution and glycerol. Different concentration of gelatin $(5,6$ and $7 \mathrm{~g}$ per $100 \mathrm{ml}$ aloe vera gel solution) and different concentration of Aloe vera $(90,80$ and $70 \mathrm{ml}$ per $10 \mathrm{ml}, 20 \mathrm{ml}, 30 \mathrm{ml}$ nanoparticles with water respectively) were used for the production of the films. The standard solution $(100 \mathrm{ml})$ for the film was prepared using $90 \mathrm{ml}$ of aloe vera gel and $10 \mathrm{ml}$ of distilled water with $\mathrm{ZnO}$ nanoparticles. Different concentration of Aloe vera $(90 \%, 80 \%$ and $70 \%)$ was first hydrated into $100 \mathrm{ml}$ of standard solution at room temperature, and was later solubilized at $50^{\circ} \mathrm{C}$ followed by glycerol addition $(1 \mathrm{~g}, 2 \mathrm{~g}, 3 \mathrm{~g}$ ). The solution was then slowly agitated till the mixing of all the ingredients. Thus the film forming solution formed was then poured slowly on to a sprayed on fruits and allowed to air dry at room temperature. The edible films were then obtained on the fruits and the next day by packaged it with LDPE as discussed in earlier chapter.

\section{Evaluation of the developed composite edible film}

The result of each evaluated property of the film is discussed in detail below. 


\section{Film thickness}

The thickness varied from $0.31 \mathrm{~mm}$ to $0.42 \mathrm{~mm}$ as shown in the graph below. On comparing the thickness of the films, it was observed that the thickness increased with increasing concentration of glycerol and nanoparticles solution. The film with highest concentration of glycerol (3g) and nanoparticles solution $(10 \mathrm{~g})$ was the thickest film with thickness $0.42 \mathrm{~mm}$, whereas the film with $1 \mathrm{~g}$ glycerol and $30 \mathrm{~g}$ nanoparticles solution was the thinnest film with thickness of $0.31 \mathrm{~mm}$. This shows that as the solutes concentration increased in the film forming solution, it increased the dry matter content of the film and hence this increased the thickness. Similar results for film thickness were reported by Yehuala and Emire (2013), in this work edible film based on papaya leaf extract, aloe vera gel, nanoparticles solution and glycerol were prepared and the film properties were evaluated.

\section{Percentage transparency / transmittance}

Percentage transparency or transmittance of the developed films was determined using a UV spectrophotometer at a wavelength of $600 \mathrm{~nm}$. The value varied from $25.2 \%$ to $48.3 \%$ as shown in the table below. It was observed that the percentage transmittance increased with increasing concentration of both nanoparticles solution and glycerol. This is due to the fact that the molecules present in glycerol and nanoparticles solution does not absorb much light.

Similar results for film transparency were reported by Yehuala and Emire (2013), in this work edible films based on papaya leaf extract, aloe vera gel, nanoparticles solution and glycerol were produced and similar effects of nanoparticles solution and glycerol concentration on film transmittance was observed.

\section{Mechanical properties of composite edible films}

Two of the mechanical properties tensile strength and percentage elongation of the film was determined. The concentration of both Aloe vera and glycerol had significant effect $(p<0.05)$ on the tensile strength of the film, as the nanoparticles concentration increased an increasing trend of tensile strength was observed. As the glycerol concentration increased it decreased the tensile strength, this is because the addition of plasticizer reduces the forces between the chains of macromolecules which increases the free volume and hence decreases tensile strength reported by sobral et al., (2001). Both glycerol and nanoparticles had significant effect $(p<0.05)$ on percentage elongation of the films, it increased with increase in the concentration of both. The following results are in line with the findings of Yehuala and Emire (2013), in this work edible film based on papaya leaf extract, aloe vera gel, nanoparticles and glycerol were prepared and similar effects of glycerol and nanoparticles solution concentration on tensile strength and percentage elongation was observed.

\section{Sealability of the edible film}

Sealability was determined by forming small pouches of the edible films. The results indicated that the film with lowest content of aloe vera was perfectly sealable whereas film with high content of aloe vera did not seal properly. Only some of the films such as $\mathrm{T}_{(1,7)}$, $\mathrm{T}_{(2,7)}, \mathrm{T}_{(2,8)}, \mathrm{T}_{(3,7)}$ and $\mathrm{T}_{(3,8)}$ showed good sealability.

\section{Evaluation of quality parameters of mango}

\section{Percentage weight loss}

Weight loss is primarily associated with the fruit respiration and evaporation of moisture. 
All the fruits coated with different formulations including control showed the same trend of weight loss during the storage period. The percentage weight loss increased with increase in the storage period, however the rate of weight loss was different for all the coated fruits depending upon the composition of the coating.

The graphs below show the effect of both $\mathrm{ZnO}$ nanoparticles and glycerol on the percentage weight loss of the coated fruits. It was observed that percentage weight loss decreased as the concentration of the glycerol decreased and the concentration of nanoparticles increased. This is due to the fact that as the concentration of the nanoparticles increased, it enabled closing most of the fruit pores which in turn reduced the respiration rate and hence reduced percentage weight loss.

Glycerol is capable of decreasing the intermolecular forces when added as a plasticizer, and hence addition of increased amount of glycerol increases the inter chain lubrication and hence makes the coating more vulnerable to moisture loss.

Therefore glycerol when added into the coating formulation at low concentration will decrease the \% weight loss. The following results are in line with the results obtained by Oluwaseun et al., (2013), this study involved coating of cucumber with a combination of aloe vera gel and chitosan. Chitosan alone and aloe vera gel alone, then storing them for 1 week at ambient conditions, the weight loss increased with increasing period of storage.

The coating with aloe vera gel and chitosan, chitosan alone were able to reduce weight loss during the storage. Olivas and Canovas (2005) reported that if glycerol concentration in any film formulation increases, it highly increases the affinity of the coating towards water.

\section{Percentage total acidity}

The $\%$ total acidity here was calculated in terms of percentage citric acid present in the fruit, it decreased with increase in the storage period in case of all the coated and control fruits. Fruits continue to respire when they are stored after harvesting, that is when the prevalent acids present in them act as substrates for the various enzymatic reactions which take place during respiration reported by Banks (1984) and Cano et al., (1997). Hence during storage when the respiration in fruits increases the citric acid present in them is broken down to sugars which decreases the citric acid content and thus decreases the percentage total acid.

Here the concentration of glycerol in the coating had a significant effect on the percentage total acidity of the Mangoes. As the glycerol content increased the percentage total acidity decreased, this is because of the fact that glycerol acts as a plasticizer and helps in binding the coating together an increase in the glycerol decreases the intermolecular forces in the coating and hence this increases the rate of respiration which in turn decreases the $\%$ total acidity. The concentration of nanoparticles solution also had a significant effect on the percentage total acidity. As the nanoparticles solution concentration increased it increased the percentage total acid because the nanoparticles content in the coating would have filled all the cracks (if any) and pores of the fruits surface through which they respire and hence decreased the rate of respiration.

The following results are in line with the findings of Gol and Rao (2013), here an edible coating based on nanoparticles solution were developed for mango fruits and the quality attributes were evaluated during storage at ambient conditions. The coating with highest nanoparticles solution content gave the highest $\%$ total acidity. 


\section{Equipments Used}

\begin{tabular}{|c|c|c|c|}
\hline S.NO & Equipment & Use & Model No \\
\hline 1 & $\begin{array}{l}\text { Digital Weighing } \\
\text { Balance }\end{array}$ & $\begin{array}{l}\text { Digital weighing balance was used to weigh the developed edible } \\
\text { film and fruit samples during the research. }\end{array}$ & LCB4A \\
\hline 2 & Blender & $\begin{array}{l}\text { The gel matrix of the aloe vera was separated from its leaves and } \\
\text { ground well in the blender without any lumps. }\end{array}$ & REX500 \\
\hline 3 & Water bath & $\begin{array}{l}\text { Water bath is an equipment filled with water into which containers } \\
\text { with the substance to be heated can be placed. The heating } \\
\text { temperature can be adjusted with the knob provided. }\end{array}$ & - \\
\hline 4 & Hot plate & $\begin{array}{l}\text { Hot plate is an equipment with a disc shaped metallic surface which } \\
\text { is heated to high temperatures. The materials to be heated are poured } \\
\text { into the glasswares and are kept on the surface of the plate directly; } \\
\text { the contents in the glasswares can be stirred occasionally with the } \\
\text { help of a glass rod to provide uniform mixing }\end{array}$ & - \\
\hline 5 & $\begin{array}{c}\text { Hand } \\
\text { refractometer }\end{array}$ & $\begin{array}{l}\text { Hand held refractometers are instruments used to determine the total } \\
\text { amount of dissolved substances in water. They are easy to handle } \\
\text { and use, are light weight and easily transportable, they should be } \\
\text { used in the presence of a good light source. They are used to measure } \\
\text { the degree brix of fruit juices and to determine the ripeness of fruits. }\end{array}$ & 82ATC \\
\hline 6 & pH Meter & $\begin{array}{l}\mathrm{pH} \text { meter is an instrument which is used to measure the } \mathrm{pH} \text { of } \\
\text { various liquid solutions, in food industry it is used to measure the } \\
\text { acidity of fruit juices, jam, jellies, fruit purees etc. the instrument } \\
\text { consists of a control panel with a digital display board and two } \\
\text { electrodes which are dipped in the solution whose pH has to be } \\
\text { determined. }\end{array}$ & - \\
\hline 7 & Desiccator & $\begin{array}{l}\text { Desiccators are tight enclosures made of glass containing desiccants } \\
\text { used for preserving materials that tend to absorb moisture from the } \\
\text { surroundings. After the preparation of the edible films, they were } \\
\text { kept inside the desiccators before their testing to avoid moisture } \\
\text { absorption }\end{array}$ & - \\
\hline 8 & $\begin{array}{l}\text { Heat Sealing } \\
\text { Machine }\end{array}$ & $\begin{array}{l}\text { Heat sealing machine was used to check the sealability of the edible } \\
\text { films produced. It has a knob to adjust the temperature of the lower } \\
\text { sealing bar and an adjustable platform to support the edge of the } \\
\text { edible film pouches. The open ends of the pouches are kept between } \\
\text { the sealing bars and the temperature is adjusted to seal the pouch }\end{array}$ & $\begin{array}{c}\text { 92DS1295 } \\
4\end{array}$ \\
\hline 9 & $\begin{array}{c}\text { Spectrophotomet } \\
\text { er }\end{array}$ & $\begin{array}{l}\text { A spectrophotometer is an instrument which gives the information } \\
\text { about how much light can be passed through the sample. It can be } \\
\text { used to record the absorbance of various liquid solutions. Here it is } \\
\text { used to measure the transparency of the composite edible films. }\end{array}$ & VIS-002 \\
\hline 10 & $\begin{array}{l}\text { Universal Testing } \\
\text { Machine (UTM) }\end{array}$ & $\begin{array}{l}\text { The universal testing machine was used to determine the tensile } \\
\text { strength and the percentage elongation of the developed composite } \\
\text { edible film samples. The load from the test samples is transmitted } \\
\text { through hydraulic power to a load indicator. Application of load is } \\
\text { done by a hydrostatically lubricated ram }\end{array}$ & $\begin{array}{c}\text { Instron33 } \\
69\end{array}$ \\
\hline
\end{tabular}




\section{Flow chart for extraction of Aloe vera gel}

Fresh aloe vera leaves were harvested

The gel matrix was separated and ground in a blender

Filtered to remove the fibers

$\downarrow$

Fresh aloe vera gel was obtained

$\downarrow$

Pasteurization $\left(50^{\circ} \mathrm{C}\right.$ for $\left.15 \mathrm{~min}\right)$ Maughan et al., (1984)

$\downarrow$

Ascorbic acid (2.0 g/l) and citric acid (4.5 g/l) added (for stabilization of the gel)

\section{Flow chart for film forming}

$90 \mathrm{ml}$ of Aloe vera gel with ascorbic acid and citric acid

Glycerol $(1-3 \mathrm{~g})$ addition

$\downarrow$

Solution was kept in water bath under slight agitation for $30 \mathrm{~min}$

Add 100mg Nanoparticles with 10ml water and homogenized for 30 mins (standard solution)

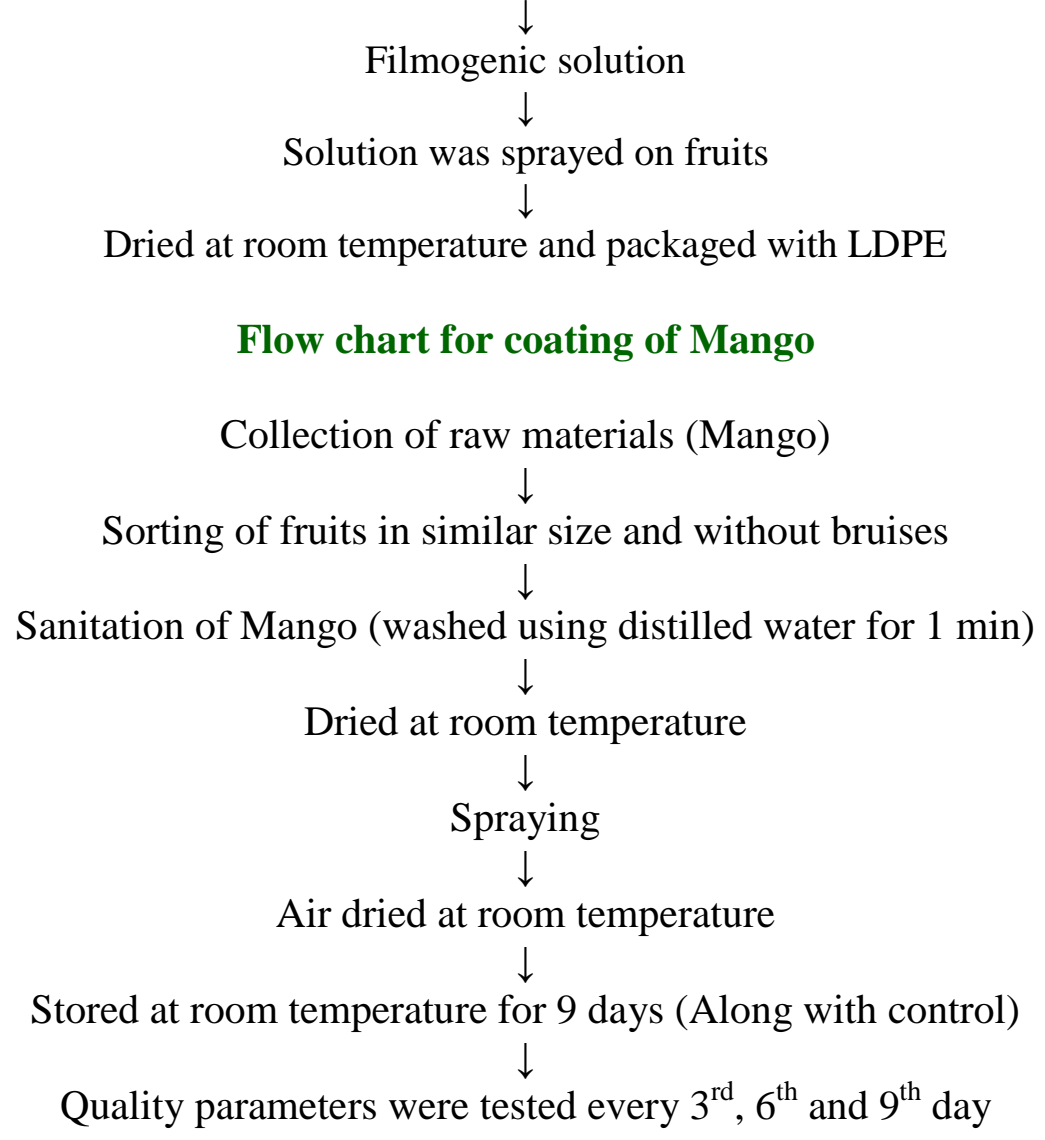


Table.1 Composition of film/coating forming solution

\begin{tabular}{|c|c|c|c|}
\hline Coating & \multicolumn{3}{|c|}{ Concentration of components } \\
\hline & Glycerol (g) & Aloe Solution (ml) & Water (ml) + NPs (100mg) \\
\hline $\mathbf{T}_{(\mathbf{1}, \mathbf{9})}$ & 1 & 90 & 10 \\
\hline $\mathbf{T}_{(\mathbf{1}, \mathbf{8}}$ & 1 & 80 & 20 \\
\hline $\mathbf{T}_{(\mathbf{1}, \mathbf{7}}$ & 1 & 70 & 30 \\
\hline $\mathbf{T}_{(\mathbf{2}, \mathbf{9}}$ & 2 & 90 & 10 \\
\hline $\mathbf{T}_{(\mathbf{2}, \mathbf{8})}$ & 2 & 80 & 20 \\
\hline $\mathbf{T}_{(\mathbf{2}, \mathbf{7}}$ & 2 & 70 & 30 \\
\hline $\mathbf{T}_{(\mathbf{3}, \mathbf{9}}$ & 3 & 90 & 10 \\
\hline $\mathbf{T}_{(\mathbf{3}, \mathbf{8})}$ & 3 & 80 & 20 \\
\hline $\mathbf{T}_{(\mathbf{3}, \mathbf{7})}$ & 3 & 70 & 30 \\
\hline
\end{tabular}

Table.2 Experimental plan for development of composite edible films

\begin{tabular}{|c|c|c|c|c|c|}
\hline Variables & Levels & \multicolumn{4}{|c|}{ Description } \\
\hline Aloe vera gel & 3 & \multicolumn{4}{|c|}{$90 \mathrm{ml}, 80 \mathrm{ml}, 70 \mathrm{ml}$ aloe vera gel } \\
\hline Distill water & 1 & \multicolumn{4}{|c|}{$10 \mathrm{ml}$ distill water } \\
\hline Plasticizer & 3 & \multicolumn{4}{|c|}{$1 \mathrm{~g}, 2 \mathrm{~g}$ and $3 \mathrm{~g}$ glycerol } \\
\hline Nanoparticles & 1 & \multicolumn{4}{|l|}{$100 \mathrm{mg}$} \\
\hline \multirow[t]{10}{*}{$\begin{array}{l}\text { Developed } \\
\text { composite } \\
\text { edible films }\end{array}$} & \multirow[t]{10}{*}{9} & Coating & $\begin{array}{l}\text { Glycerol }(\mathrm{g}) / 100 \mathrm{ml} \\
\text { Aloe vera gel } \\
\text { solution }\end{array}$ & $\begin{array}{l}\text { Aloe vera gel } \\
\text { solution }(\mathrm{ml})\end{array}$ & $\begin{array}{l}\text { NPs + } \\
\text { Water } \\
\text { (ml) }\end{array}$ \\
\hline & & $\mathrm{T}_{(1,9)}$ & 1 & 90 & 10 \\
\hline & & $\mathrm{T}_{(1,8)}$ & 1 & 80 & 20 \\
\hline & & $\mathrm{T}_{(1,7)}$ & 1 & 70 & 30 \\
\hline & & $\mathrm{T}_{(2,9)}$ & 2 & 90 & 10 \\
\hline & & $\mathrm{T}_{(2,8)}$ & 2 & 80 & 20 \\
\hline & & $\mathrm{T}_{(2,7)}$ & 2 & 70 & 30 \\
\hline & & $\mathrm{T}_{(3,9)}$ & 3 & 90 & 10 \\
\hline & & $\mathrm{T}_{(3,8)}$ & 3 & 80 & 20 \\
\hline & & $\mathrm{T}_{(3,7)}$ & 3 & 70 & 30 \\
\hline $\begin{array}{l}\text { Film } \\
\text { properties }\end{array}$ & 5 & \multicolumn{3}{|c|}{$\begin{array}{l}\text { Thickness } \\
\text { \% Transmittance } \\
\text { Mechanical properties } \\
\text { (TS and \% EB) } \\
\text { Sealability }\end{array}$} & \\
\hline $\begin{array}{l}\text { Statistical } \\
\text { analysis }\end{array}$ & 1 & \multicolumn{3}{|c|}{ ANOVA (MS EXCEL) } & \\
\hline
\end{tabular}


Table.3 Experimental plan for edible coating of Mango

\begin{tabular}{|c|c|c|c|c|c|}
\hline Variables & Levels & \multicolumn{4}{|c|}{ Description } \\
\hline Products & 1 & \multicolumn{4}{|c|}{ Mango (Magnifera indica) } \\
\hline Sorting & \multirow{2}{*}{$\begin{array}{l}1 \\
1\end{array}$} & \multicolumn{4}{|c|}{ Sorting of Mangoes in similar ripeness } \\
\hline Sanitation & & \multicolumn{4}{|c|}{ Rinsing in Distilled water for $1 \mathrm{~min}$} \\
\hline \multirow[t]{10}{*}{$\begin{array}{l}\text { Edible } \\
\text { coating }\end{array}$} & \multirow[t]{10}{*}{9} & Coating & $\begin{array}{c}\text { Glycerol }(\mathrm{g}) / \\
100 \mathrm{ml} \text { aloe } \\
\text { vera gel } \\
\text { solution }\end{array}$ & $\begin{array}{l}\text { Aloe vera gel } \\
\text { solution (ml) }\end{array}$ & $\begin{array}{l}\text { NPs + Water } \\
(\mathrm{ml})\end{array}$ \\
\hline & & $\mathrm{T}_{(1,9)}$ & 1 & 90 & 10 \\
\hline & & $\mathrm{T}_{(1,8)}$ & 1 & 80 & 20 \\
\hline & & $\mathrm{T}_{(1,7)}$ & 1 & 70 & 30 \\
\hline & & $\mathrm{T}_{(2,9)}$ & 2 & 90 & 10 \\
\hline & & $\mathrm{T}_{(2,8)}$ & 2 & 80 & 20 \\
\hline & & $\mathrm{T}_{(2,7)}$ & 2 & 70 & 30 \\
\hline & & $\mathrm{T}_{(3,9)}$ & 3 & 90 & 10 \\
\hline & & $\mathrm{T}_{(3,8)}$ & 3 & 80 & 20 \\
\hline & & $\mathrm{T}_{(3,7)}$ & 3 & 70 & 30 \\
\hline $\begin{array}{l}\text { Storage } \\
\text { condition }\end{array}$ & 1 & \multicolumn{3}{|c|}{ At room temperature for 9 days } & \\
\hline $\begin{array}{l}\text { Quality } \\
\text { parameters }\end{array}$ & 5 & \multicolumn{3}{|c|}{$\begin{array}{l}\% \text { weight loss, } \% \text { total acidity, ascorbic acid, } \\
\text { TSS and } \mathrm{pH} .\end{array}$} & \\
\hline $\begin{array}{l}\text { Statistical } \\
\text { analysis }\end{array}$ & 1 & \multicolumn{3}{|c|}{ ANOVA (MS EXCEL) } & \\
\hline
\end{tabular}

Table.4 Skeleton of ANOVA Table

\begin{tabular}{l|l|l|l|l|l|}
$\begin{array}{l}\text { Source of } \\
\text { Variation }\end{array}$ & \multicolumn{1}{|c|}{ Df } & \multicolumn{1}{|c|}{ SS } & \multicolumn{1}{|c|}{ MSS } & \multicolumn{1}{|c|}{$\mathbf{F}_{\text {Cal }}$} & $\mathbf{F}_{\text {Tab }}$ \\
\hline Treatment & $\mathrm{t}-1$ & TrSS & $\begin{array}{l}\text { SSA/t- } \\
1=\text { MSSA }\end{array}$ & MSSA/MESS & 4.06 \\
\hline Error & N-t & ErSS & $\begin{array}{l}\text { ErSS/(t-1)(r- } \\
1)=\text { MESS }\end{array}$ & \\
\hline Total & N-1 & TSS & TSS/N-1 & \\
\hline
\end{tabular}


Table.5 Thickness of the developed composite edible films

\begin{tabular}{|c|c|c|}
\hline Film name & \multicolumn{2}{|c|}{ Thickness (mm) } \\
\hline $\mathbf{T}_{(1,7)}$ & & 0.31 \\
\hline$T_{(1,8)}$ & & 0.34 \\
\hline$T_{(1,9)}$ & & 0.39 \\
\hline $\mathbf{T}_{(2,7)}$ & & 0.33 \\
\hline $\mathbf{T}_{(2,8)}$ & & 0.36 \\
\hline $\mathbf{T}_{(2,9)}$ & & 0.4 \\
\hline $\mathbf{T}_{(3,7)}$ & & 0.34 \\
\hline $\mathbf{T}_{(3,8)}$ & & 0.38 \\
\hline $\mathbf{T}_{(3,9)}$ & & 0.42 \\
\hline Results & Due to glycerol & Due to nanoparticles \\
\hline F-Test & $\mathrm{S}$ & $\mathrm{S}$ \\
\hline S.Ed & 0.023 & 0.008 \\
\hline CD (at 5\% significance) & 0.159 & 0.055 \\
\hline
\end{tabular}

Table.6 Percentage transmittance of the developed composite edible films

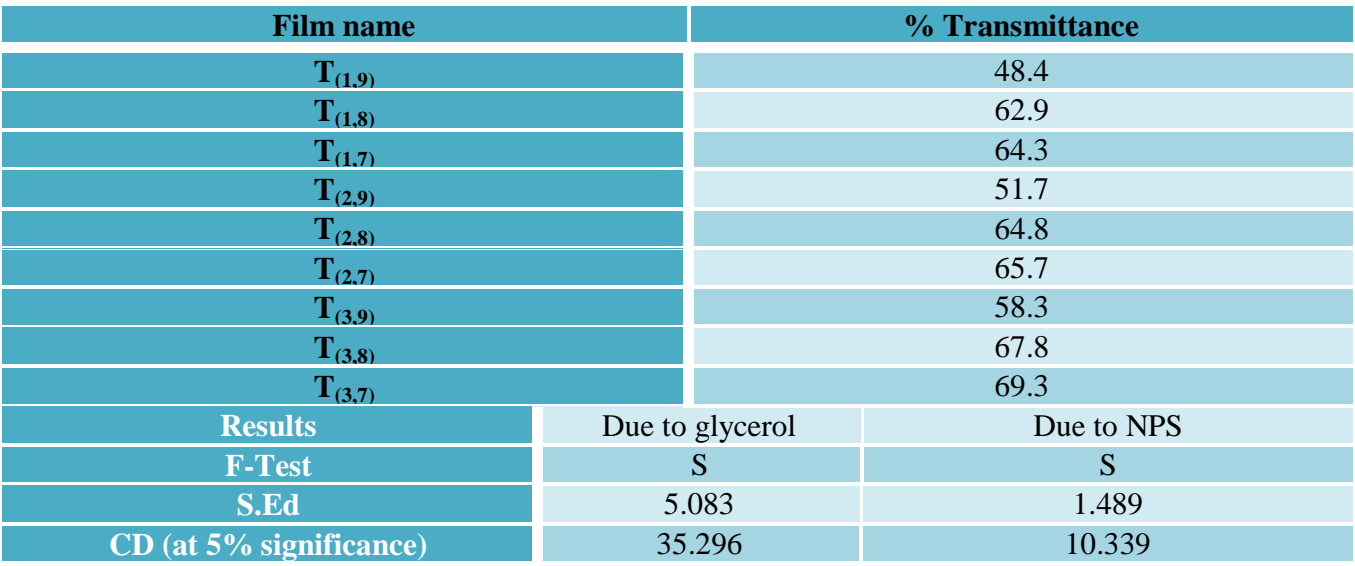

Table.7 Mechanical properties of the composite edible films

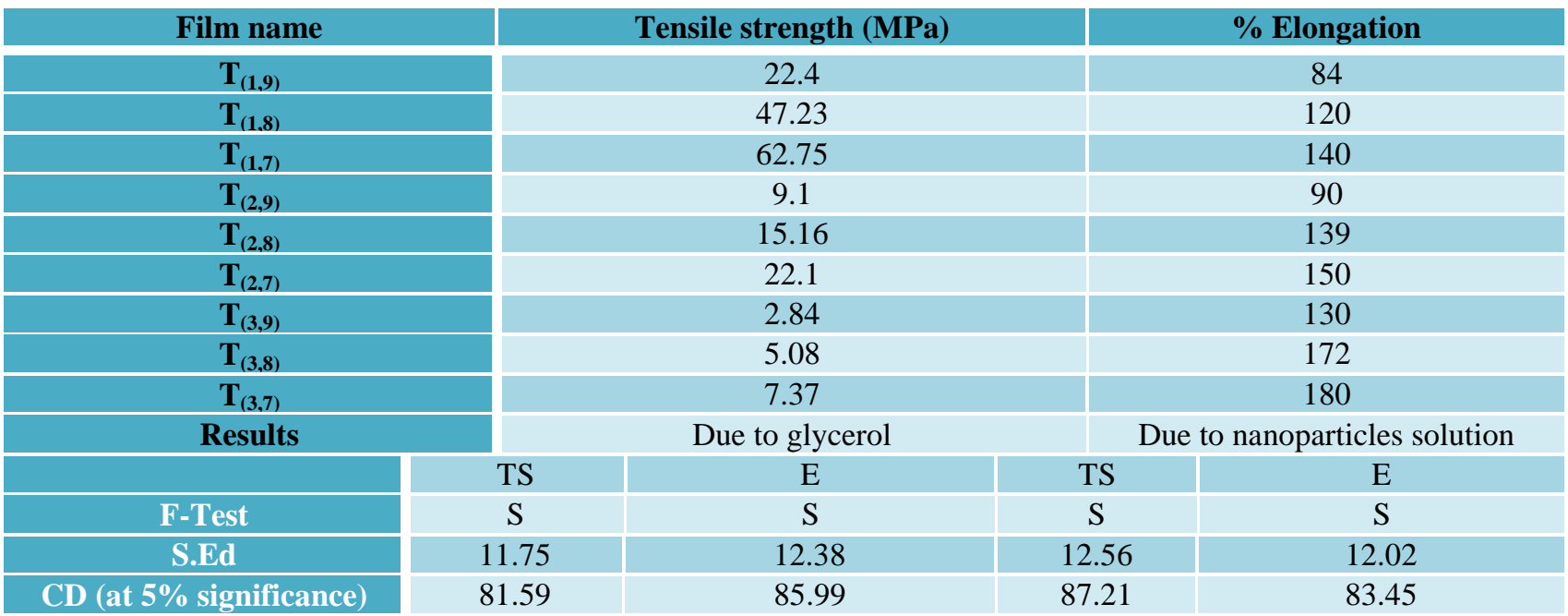


Table.8 \% WL of coated mangoes during storage (1g glycerol formulations)

\begin{tabular}{|c|c|c|c|}
\hline Coating name & \multicolumn{3}{|c|}{ Weight loss $(\%)$ during Storage } \\
\hline & $\mathbf{3}^{\text {rd }}$ day & $\mathbf{6}^{\text {th }}$ day & $\mathbf{9}^{\text {th }}$ day \\
\hline Control & 5 & 8.57 & 12.79 \\
\hline $\mathbf{T}_{(\mathbf{1 , 9})}$ & 4.23 & 4.74 & 5.51 \\
\hline $\mathbf{T}_{(\mathbf{1 , 8})}$ & 3.11 & 3.48 & 3.57 \\
\hline $\mathbf{T}_{(\mathbf{1 , 7})}$ & 2 & 2.36 & 3.08 \\
\hline F-Test & & $\mathrm{S}$ & \\
\hline S.Ed & & 0.317 & \\
\hline CD (at 5\% & & 1.272 & \\
\hline significance) & & & \\
\hline
\end{tabular}

Table.9 \% WL of coated mangoes during storage ( $2 \mathrm{~g}$ glycerol formulation)

\begin{tabular}{|c|c|c|c|}
\hline Coating name & \multicolumn{3}{|c|}{ Weight loss $(\%)$ during Storage } \\
\hline Control & $\mathbf{3}^{\text {rd }} \mathbf{d a y}$ & $\mathbf{6}^{\text {th }}$ day & $\mathbf{9}^{\text {th }}$ day \\
\hline $\mathrm{T}_{(2,9)}$ & 6.87 & 10.24 & 15 \\
\hline $\mathrm{T}_{(\mathbf{2}, 8)}$ & 4.78 & 5.12 & 5.37 \\
\hline $\mathrm{T}_{(2,7)}$ & 3.98 & 4.15 & 4.5 \\
\hline F-Test & 3.08 & 3.55 & 4.28 \\
\hline S.Ed & & $\mathrm{S}$ & \\
\hline CD (at 5\% significance) & & 0.349 & \\
\hline & & 1.419 & \\
\hline
\end{tabular}

Table.10 \% WL of coated mangoes during storage (3g glycerol Formulation)

\begin{tabular}{|c|c|c|c|}
\hline Coating name & \multicolumn{3}{|c|}{ Weight loss $(\%)$ during Storage } \\
\hline Control & $\mathbf{3}^{\text {rd }} \mathbf{d a y}$ & $\mathbf{6}^{\text {th }} \mathbf{d a y}$ & $\mathbf{9}^{\text {th }} \mathbf{d a y}$ \\
\hline $\mathrm{T}_{(3,9)}$ & 6 & 14 & 18.57 \\
\hline $\mathrm{T}_{(3,8)}$ & 5.4 & 5.99 & 6.83 \\
\hline $\mathrm{T}_{(3,7)}$ & 4.92 & 5.74 & 6.47 \\
\hline F-Test & 4.62 & 5.24 & 5.81 \\
\hline S.Ed & & $\mathrm{S}$ & \\
\hline CD (at 5\% & & 0.344 & \\
\hline significance) & & 1.377 & \\
\hline
\end{tabular}


Table.11 Effect of glycerol on \% weight loss of mango

\begin{tabular}{|c|c|c|c|c|c|}
\hline $\begin{array}{c}\text { Coating } \\
\text { name }\end{array}$ & $\begin{array}{c}\text { Nanoparticles } \\
\text { Solution }(\mathbf{m l})\end{array}$ & $\begin{array}{c}\text { Glycerol } \\
(\mathbf{g})\end{array}$ & \multicolumn{3}{|c|}{ Weight loss (\%) during } \\
& & & $\mathbf{3}^{\text {rd }} \mathbf{\text { day }}$ & $\mathbf{6}^{\text {th }}$ day & $\mathbf{9}^{\text {th }}$ day \\
\hline Control & 0 & 0 & 7 & 15.91 & 19 \\
\hline $\mathbf{T}_{(\mathbf{1}, \mathbf{7})}$ & 30 & 1 & 2 & 2.36 & 3.08 \\
\hline $\mathbf{T}_{(\mathbf{2}, \mathbf{7})}$ & 30 & 2 & 3.08 & 3.55 & 4.28 \\
\hline $\mathbf{T}_{(\mathbf{3}, \mathbf{7})}$ & 30 & 3 & 4.62 & 5.24 & 5.81 \\
\hline F-Test & & $\mathrm{S}$ & & & \\
\hline S.Ed & & 0.317 & & & \\
\hline $\begin{array}{c}\text { CD (at 5\% } \\
\text { significance) }\end{array}$ & & 1.290 & & & \\
\hline
\end{tabular}

Table.12 \% TA of coated mangoes during storage (1g glycerol Formulation)

\begin{tabular}{|c|c|c|c|}
\hline Coating name & \multicolumn{3}{|c|}{ Total acidity (\%) during Storage } \\
\hline & $\mathbf{3}^{\text {rd }} \mathbf{d a y}$ & $\mathbf{6}^{\text {th }}$ day & $\mathbf{9}^{\text {th }}$ day \\
\hline Control & 0.12 & 0.12 & 0.11 \\
\hline $\mathbf{T}_{(\mathbf{1}, \mathbf{9})}$ & 0.22 & 0.21 & 0.18 \\
\hline $\mathbf{T}_{(\mathbf{1}, \mathbf{8})}$ & 0.25 & 0.23 & 0.20 \\
\hline $\mathbf{T}_{(\mathbf{1}, \mathbf{7})}$ & 0.29 & 0.27 & 0.25 \\
\hline F-Test & & $\mathbf{S}$ & \\
\hline S.Ed & & 0.012 & \\
\hline CD (at 5\% & & 0.048 & \\
\hline significance) & & & \\
\hline
\end{tabular}

Table.13\% TA of coated mangoes during storage ( $\mathrm{g}$ glycerol formulation)

\begin{tabular}{|c|c|c|c|}
\hline Coating name & \multicolumn{3}{|c|}{ Total acidity (\%) during Storage } \\
\hline & $\mathbf{3}^{\text {rd }} \mathbf{d a y}$ & $\mathbf{6}^{\text {th }}$ day & $\mathbf{9}^{\text {th }}$ day \\
\hline Control & 0.14 & 0.13 & 0.12 \\
\hline $\mathbf{T}_{(\mathbf{2 , 9})}$ & 0.20 & 0.19 & 0.18 \\
\hline $\mathbf{T}_{(\mathbf{2}, \mathbf{8})}$ & 0.22 & 0.21 & 0.19 \\
\hline $\mathbf{T}_{(\mathbf{2}, \mathbf{7})}$ & 0.25 & 0.24 & 0.24 \\
\hline F-Test & & $\mathbf{S}$ & \\
\hline S.Ed & & 0.003 & \\
\hline CD (at 5\% & & 0.012 & \\
\hline significance) & & & \\
\hline
\end{tabular}


Table.14 \% TA of coated mangoes during storage (3g glycerol formulation)

\begin{tabular}{|c|c|c|c|}
\hline Coating name & \multicolumn{3}{|c|}{ Total acidity (\%) during Storage } \\
\hline & $\mathbf{3}^{\text {rd }}$ day & $\mathbf{6}^{\text {th }}$ day & $\mathbf{9}^{\text {th }}$ day \\
\hline $\mathbf{T}_{(\mathbf{1}, \mathbf{0})}$ & 0.14 & 0.14 & 0.12 \\
\hline $\mathbf{T}_{(\mathbf{1}, \mathbf{9})}$ & 0.17 & 0.16 & 0.14 \\
\hline $\mathbf{T}_{(\mathbf{1}, \mathbf{8})}$ & 0.18 & 0.17 & 0.15 \\
\hline $\mathbf{T}_{(\mathbf{1}, \mathbf{7})}$ & 0.19 & 0.17 & 0.18 \\
\hline F-Test & & $\mathbf{S}$ & \\
\hline S.Ed & & 0.005 & \\
\hline CD (at 5\% & & 0.020 & \\
\hline significance) & & & \\
\hline
\end{tabular}

Table.15 Effect of glycerol on \% total acidity of coated mango

\begin{tabular}{|c|c|c|c|c|c|}
\hline Coating name & $\begin{array}{c}\text { Nanoparticles } \\
\text { Solution }(\mathbf{m l})\end{array}$ & Glycerol (g) & \multicolumn{3}{|c|}{$\begin{array}{c}\text { \% Total acidity during } \\
\text { Storage }\end{array}$} \\
\hline & & & $\mathbf{3}^{\text {rd }}$ day & $\mathbf{6}^{\text {th }}$ day & $\mathbf{9}^{\text {th }}$ day \\
\hline Control & 0 & 0 & 0.12 & 0.11 & 0.10 \\
\hline $\mathbf{T}_{(\mathbf{1}, \mathbf{7})}$ & 30 & 1 & 0.29 & 0.27 & 0.25 \\
\hline $\mathbf{T}_{(\mathbf{2}, \mathbf{7}}$ & 30 & 2 & 0.25 & 0.24 & 0.24 \\
\hline $\mathbf{T}_{(\mathbf{3}, \mathbf{7}}$ & 30 & 3 & 0.19 & 0.17 & 0.18 \\
\hline $\mathbf{F - T e s t}$ & & $\mathbf{S}$ & & & \\
\hline S.Ed & & 0.012 & & & \\
\hline $\begin{array}{c}\text { CD (at 5\% } \\
\text { significance) }\end{array}$ & & 0.048 & & & \\
\hline
\end{tabular}

Table.16 Ascorbic acid (mg/100 g) of coated mangoes (1g glycerol)

\begin{tabular}{|c|}
\hline Film name \\
\hline \\
\hline Control \\
\hline $\mathbf{T}_{(1,9)}$ \\
\hline $\mathbf{T}_{(\mathbf{1}, \mathbf{8})}$ \\
\hline $\mathbf{T}_{(\mathbf{1}, \mathbf{7})}$ \\
\hline F-Test \\
\hline S.Ed \\
\hline CD (at 5\% significance) \\
\hline
\end{tabular}

\begin{tabular}{|c|c|c|}
\hline \multicolumn{3}{|c|}{ Ascorbic acid content during Storage } \\
\hline $3^{\text {rd }}$ day & $\mathbf{6}^{\text {th }}$ day & $\mathbf{9}^{\text {th }}$ day \\
\hline 117 & 112.49 & 105.98 \\
\hline 120.79 & 117.16 & 115 \\
\hline 123 & 120.97 & 118.74 \\
\hline 128 & 127.08 & 126 \\
\hline & $\mathrm{S}$ & \\
\hline & 0.578 & \\
\hline
\end{tabular}


Table.17 Ascorbic acid (mg/100 g) of coated mangoes (2g glycerol)

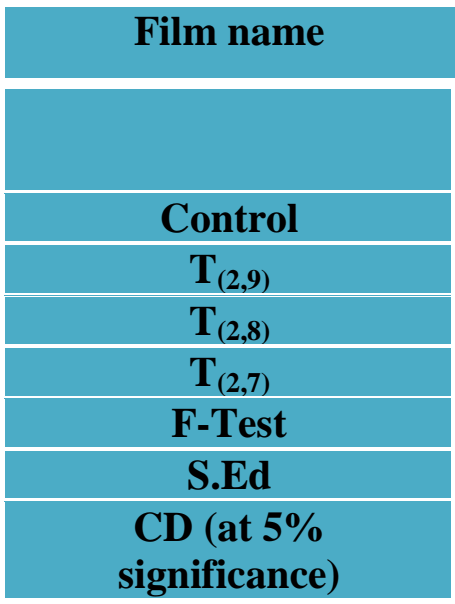

Ascorbic acid content during Storage

\begin{tabular}{|c|c|c|}
\hline $3^{\text {rd }} \mathbf{d a y}$ & $\mathbf{6}^{\text {th }} \mathbf{d a y}$ & $\mathbf{9}^{\text {th }} \mathbf{d a y}$ \\
\hline 114 & 106.2 & 102 \\
\hline 118.21 & 113.32 & 108 \\
\hline 126.44 & 120 & 114 \\
\hline 130.3 & 126.05 & 120 \\
\hline & $\mathrm{S}$ & \\
\hline & 2.988 & \\
\hline & 12.15 & \\
\hline
\end{tabular}

Table.18 Ascorbic acid (mg/100 g) of coated mangoes (3g glycerol)

\begin{tabular}{|c|}
\hline Film name \\
\hline \\
\hline Control \\
\hline $\mathbf{T}_{(3,9)}$ \\
\hline $\mathbf{T}_{(\mathbf{3}, \mathbf{8})}$ \\
\hline $\mathbf{T}_{(\mathbf{3}, 7)}$ \\
\hline F-Test \\
\hline S.Ed \\
\hline CD (at 5\% \\
\hline significance) \\
\hline
\end{tabular}

Ascorbic acid content during Storage

\begin{tabular}{|c|c|c|}
$\mathbf{3}^{\text {rd }} \mathbf{d a y}$ & $\mathbf{6}^{\text {th }} \mathbf{d a y}$ & $\mathbf{9}^{\text {th }} \mathbf{d a y}$ \\
\hline 111 & 103 & 98 \\
\hline 120.93 & 116 & 112 \\
\hline 124.98 & 121 & 117.85 \\
\hline 129.9 & 125 & 123 \\
\hline & $\mathrm{S}$ & \\
\hline & 2.049 & \\
\hline & 8.33 & \\
\hline
\end{tabular}

Table.19 Effect of glycerol on \% ascorbic acid of coated mango

\begin{tabular}{|c|c|c|c|c|c|}
\hline $\begin{array}{c}\text { Coating } \\
\text { name }\end{array}$ & $\begin{array}{c}\text { Nanoparticle } \\
\text { Solution (ml) }\end{array}$ & Glycerol (g) & \multicolumn{3}{|c|}{$\begin{array}{c}\text { Ascorbic acid during } \\
\text { Storage }\end{array}$} \\
\hline & & & $3^{\text {rd }}$ day & $\mathbf{6}^{\text {th }}$ day & $\mathbf{9}^{\text {th }}$ day \\
\hline Control & 0 & 0 & 100 & 95 & 86 \\
\hline $\mathbf{T}_{(\mathbf{1}, \mathbf{7}}$ & 30 & 1 & 128 & 127.08 & 126 \\
\hline $\mathbf{T}_{(\mathbf{2}, \mathbf{7}}$ & 30 & 2 & 130.3 & 126.05 & 120 \\
\hline $\mathbf{T}_{(\mathbf{3}, \mathbf{7})}$ & 30 & 3 & 129.9 & 125 & 123 \\
\hline $\mathbf{F - T e s t}$ & & $\mathbf{S}$ & & & \\
\hline S.Ed & & 0.577 & & & \\
\hline $\begin{array}{c}\text { CD (at 5\% } \\
\text { significance) }\end{array}$ & & 2.35 & & & \\
\hline
\end{tabular}


Table.20 Total soluble solids of coated mangoes (pulp) (1g glycerol)

\begin{tabular}{|c|c|c|c|}
\hline & \multicolumn{3}{|c|}{ Total soluble solids } \\
& $\mathbf{3}^{\text {rd }}$ day & $\mathbf{6}^{\text {th }}$ day & $\mathbf{9}^{\text {th }}$ day \\
\hline Control & 14.33 & 15 & 16 \\
\hline $\mathbf{T}_{(\mathbf{1}, \mathbf{9}}$ & 9.66 & 10 & 10.33 \\
\hline $\mathbf{T}_{(\mathbf{1 , 8})}$ & 9 & 9.66 & 10.33 \\
\hline $\mathbf{T}_{(\mathbf{1}, \mathbf{7})}$ & 8.66 & 9 & 9.33 \\
\hline F-Test & & $\mathrm{S}$ & \\
\hline S.Ed & & 0.193 & \\
\hline CD (at 5\% & & 0.785 & \\
\hline significance) & & & \\
\hline
\end{tabular}

Table.21 Total soluble solids of coated mangoes (pulp) (2g glycerol)

\begin{tabular}{|c|c|c|c|}
\hline & \multicolumn{3}{|c|}{ Total soluble solids } \\
\hline & $\mathbf{3}^{\text {rd }}$ day & $\mathbf{6}^{\text {th }}$ day & $\mathbf{9}^{\text {th }}$ day \\
\hline Control & 15.33 & 16 & 16.66 \\
\hline $\mathbf{T}_{(\mathbf{2}, \mathbf{9})}$ & 12 & 12.66 & 13 \\
\hline $\mathbf{T}_{(\mathbf{2}, \mathbf{8})}$ & 12 & 12.66 & 12.66 \\
\hline $\mathbf{T}_{(\mathbf{2}, \mathbf{7})}$ & 10 & 10.33 & 10.66 \\
\hline F-Test & & $\mathrm{S}$ & \\
\hline S.Ed & & 0.191 & \\
\hline C.D (5\% & & 0.78 & \\
\hline significance) & & & \\
\hline
\end{tabular}

Table.22 Total soluble solids of coated mangoes (pulp) (3g glycerol)

\begin{tabular}{|c|c|c|c|}
\hline Film name & \multicolumn{3}{|c|}{ Total soluble solids } \\
\hline & $\mathbf{3}^{\text {rd }} \mathbf{d a y}$ & $\mathbf{6}^{\text {th }}$ day & $\mathbf{9}^{\text {th }}$ day \\
\hline Control & 16.33 & 16.66 & 17 \\
\hline $\mathbf{T}_{(\mathbf{3}, \mathbf{9})}$ & 12.33 & 12.33 & 13 \\
\hline $\mathbf{T}_{(\mathbf{3}, \mathbf{8})}$ & 13 & 13 & 13.66 \\
\hline $\mathbf{T}_{(\mathbf{3}, \mathbf{7})}$ & 12.33 & 13 & 13 \\
\hline F-Test & & $\mathrm{S}$ & \\
\hline S.Ed & & 0.223 & \\
\hline C.D & & 0.91 & \\
\hline
\end{tabular}


Table.23 Effect of glycerol on TSS of coated mangoes

\begin{tabular}{|c|c|c|c|c|c|}
\hline $\begin{array}{c}\text { Coating } \\
\text { name }\end{array}$ & $\begin{array}{c}\text { Nanoparticles } \\
\text { Solution }(\mathbf{m l})\end{array}$ & Glycerol (g) & \multicolumn{3}{|c|}{ TSS during storage } \\
\hline & & & $\mathbf{3}^{\text {rd }}$ day & $\mathbf{6}^{\text {th }}$ day & $\mathbf{9}^{\text {th }}$ day \\
\hline Control & 0 & 0 & 15 & 16 & 17 \\
\hline $\mathbf{T}_{(\mathbf{1}, \mathbf{7})}$ & 30 & 1 & 8.66 & 9 & 9.33 \\
\hline $\mathbf{T}_{(\mathbf{2}, \mathbf{7}}$ & 30 & 2 & 10 & 10.33 & 10.66 \\
\hline $\mathbf{T}_{(\mathbf{3}, \mathbf{7}}$ & 30 & 3 & 12.33 & 13 & 13 \\
\hline $\mathbf{F}-\mathbf{T e s t}$ & & $\mathbf{S}$ & & & \\
\hline S.Ed & & 0.193 & & & \\
\hline C.D & & 0.79 & & & \\
\hline
\end{tabular}

Table.24 $\mathrm{pH}$ of coated mangoes during storage (1g glycerol formulation)

\begin{tabular}{|c|c|c|c|}
\hline & \multicolumn{3}{|c|}{$\mathbf{p H}$ of pulp during Storage } \\
\hline & $\mathbf{3}^{\text {rd }} \mathbf{d a y}$ & $\mathbf{6}^{\text {th }} \mathbf{d a y}$ & $\mathbf{9}^{\text {th }}$ day \\
\hline Control & 5.52 & 5.52 & 5.53 \\
\hline $\mathbf{T}_{(\mathbf{1}, \mathbf{9})}$ & 4.62 & 4.63 & 4.7 \\
\hline $\mathbf{T}_{(\mathbf{1}, \mathbf{8})}$ & 4.33 & 4.35 & 4.37 \\
\hline $\mathbf{T}_{(\mathbf{1}, \mathbf{7})}$ & 4.24 & 4.25 & 4.26 \\
\hline F-Test & & $\mathbf{S}$ & \\
\hline S.Ed & & 0.006 & \\
\hline C.D & & 0.024 & \\
\hline
\end{tabular}

Table.25 $\mathrm{pH}$ of coated mangoes during storage ( $\mathrm{g}$ glycerol formulation)

\begin{tabular}{|c|c|c|c|}
\hline Coating & \multicolumn{3}{|c|}{ pH of pulp during Storage } \\
\hline & $3^{\text {rd }}$ day & $\mathbf{6}^{\text {th }}$ day & $\mathbf{9}^{\text {th }}$ day \\
\hline Control & 5 & 5.59 & 5.78 \\
\hline $\mathbf{T}_{(\mathbf{2}, \mathbf{9})}$ & 4.70 & 4.71 & 4.72 \\
\hline $\mathbf{T}_{(\mathbf{2}, \mathbf{8})}$ & 4.52 & 4.56 & 4.58 \\
\hline $\mathbf{T}_{(\mathbf{2}, \mathbf{7})}$ & 4.24 & 4.26 & 4.27 \\
\hline F-Test & & $\mathbf{S}$ & \\
\hline S.Ed & & 0.009 & \\
\hline C.D & & 0.036 & \\
\hline
\end{tabular}


Table.26 $\mathrm{pH}$ of coated mangoes during storage ( $3 \mathrm{~g}$ glycerol formulation)

\begin{tabular}{|c|c|c|c|}
\hline Film name & \multicolumn{3}{|c|}{ pH of pulp during Storage } \\
\hline & $\mathbf{3}^{\text {rd }} \mathbf{d a y}$ & $\mathbf{6}^{\text {th }}$ day & $\mathbf{9}^{\text {th }}$ day \\
\hline control & 5.74 & 5.76 & 5.95 \\
\hline $\mathbf{T}_{(\mathbf{3}, \mathbf{9})}$ & 4.74 & 4.75 & 4.75 \\
\hline $\mathbf{T}_{(3,8)}$ & 4.55 & 4.56 & 4.56 \\
\hline $\mathbf{T}_{(3,7)}$ & 4.24 & 4.24 & 4.27 \\
\hline F-Test & & S & \\
\hline S.Ed & & 0.01 & \\
\hline C.D & & 0.04 & \\
\hline
\end{tabular}

Table.27 Effect of glycerol on $\mathrm{pH}$ of coated mangoes

\begin{tabular}{|c|c|c|c|c|c|}
\hline Coating name & $\begin{array}{c}\text { Nanoparticles } \\
\text { Solution }(\mathbf{m l})\end{array}$ & $\begin{array}{c}\text { Glycerol } \\
(\mathbf{g})\end{array}$ & \multicolumn{3}{|c|}{$\mathbf{p H}$ of pulp during Storage } \\
\hline & & & $\mathbf{3}^{\text {rd }} \mathbf{d a y}$ & $\mathbf{6}^{\text {th }}$ day & $\mathbf{9}^{\text {th }}$ day \\
\hline Control & 0 & 0 & 5.91 & 5.98 & 5.98 \\
\hline $\mathbf{T}_{(\mathbf{1}, \mathbf{7})}$ & 30 & 1 & 4.24 & 4.25 & 4.26 \\
\hline $\mathbf{T}_{(\mathbf{2}, 7)}$ & 30 & 2 & 4.24 & 4.26 & 4.27 \\
\hline $\mathbf{T}_{(3,7)}$ & 30 & 3 & 4.24 & 4.24 & 4.27 \\
\hline F-Test & & S & & & \\
\hline S.Ed & & 0.006 & & & \\
\hline C.D & & 0.024 & & & \\
\hline
\end{tabular}

Fig.1 Agriculture farms of Dasheri Mango in Malihabad, Lucknow

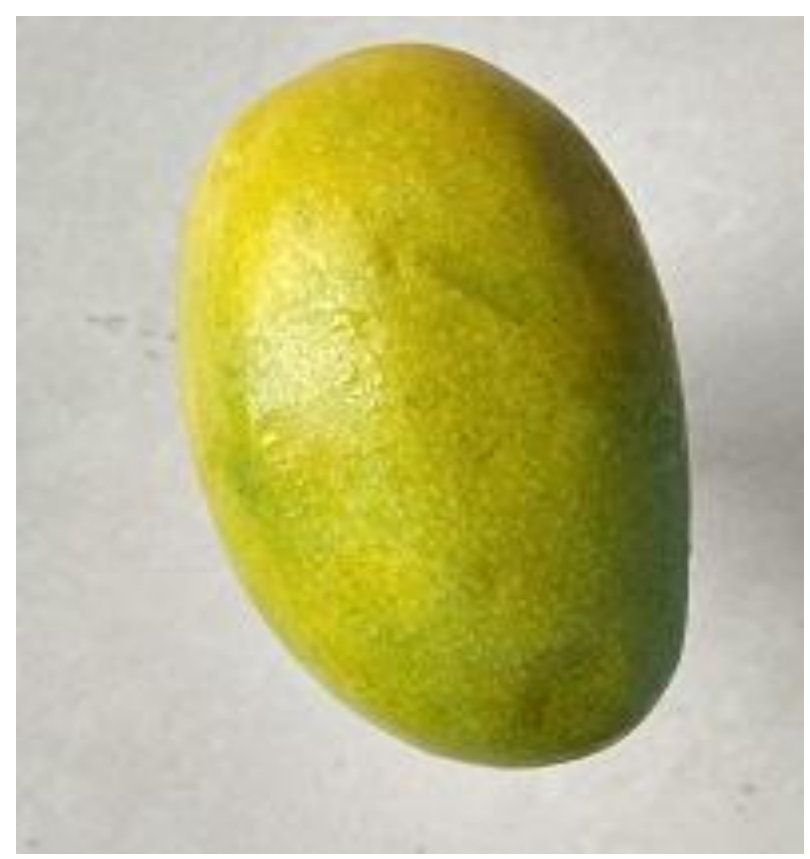


Fig.2 $\mathrm{ZnO}$ nanoparticles and blended Aloe vera solution
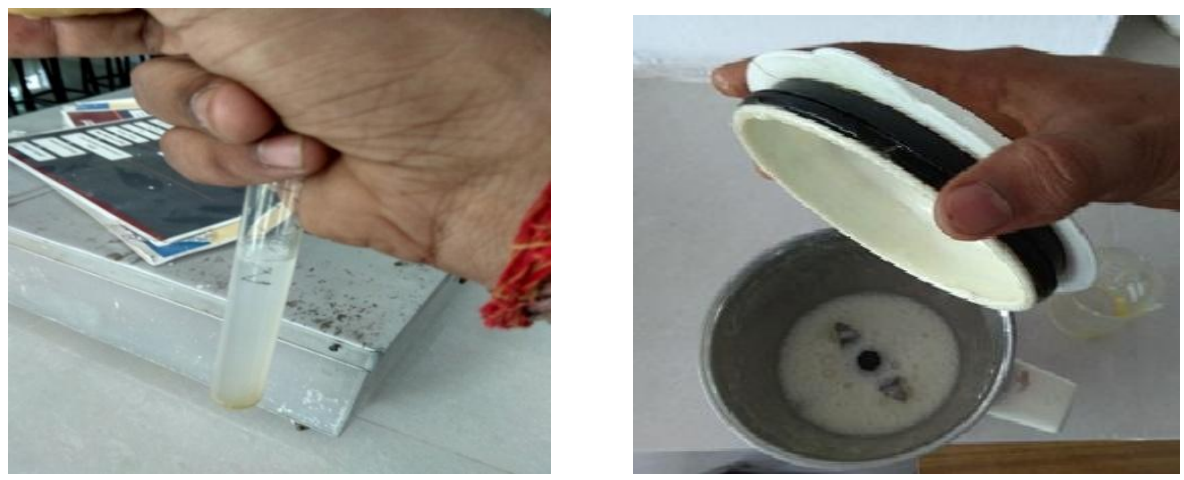

Fig.3 Aloe vera gel film forming solution and different ratios of nanocomposite edible films
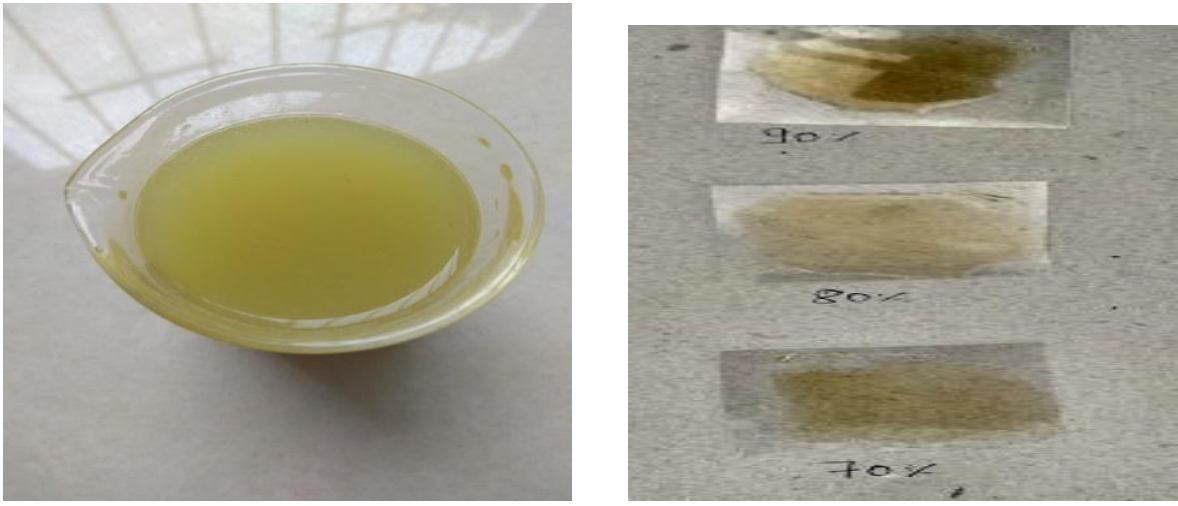

Fig.4 Effect of concentration of glycerol and nanoparticles on the film thickness

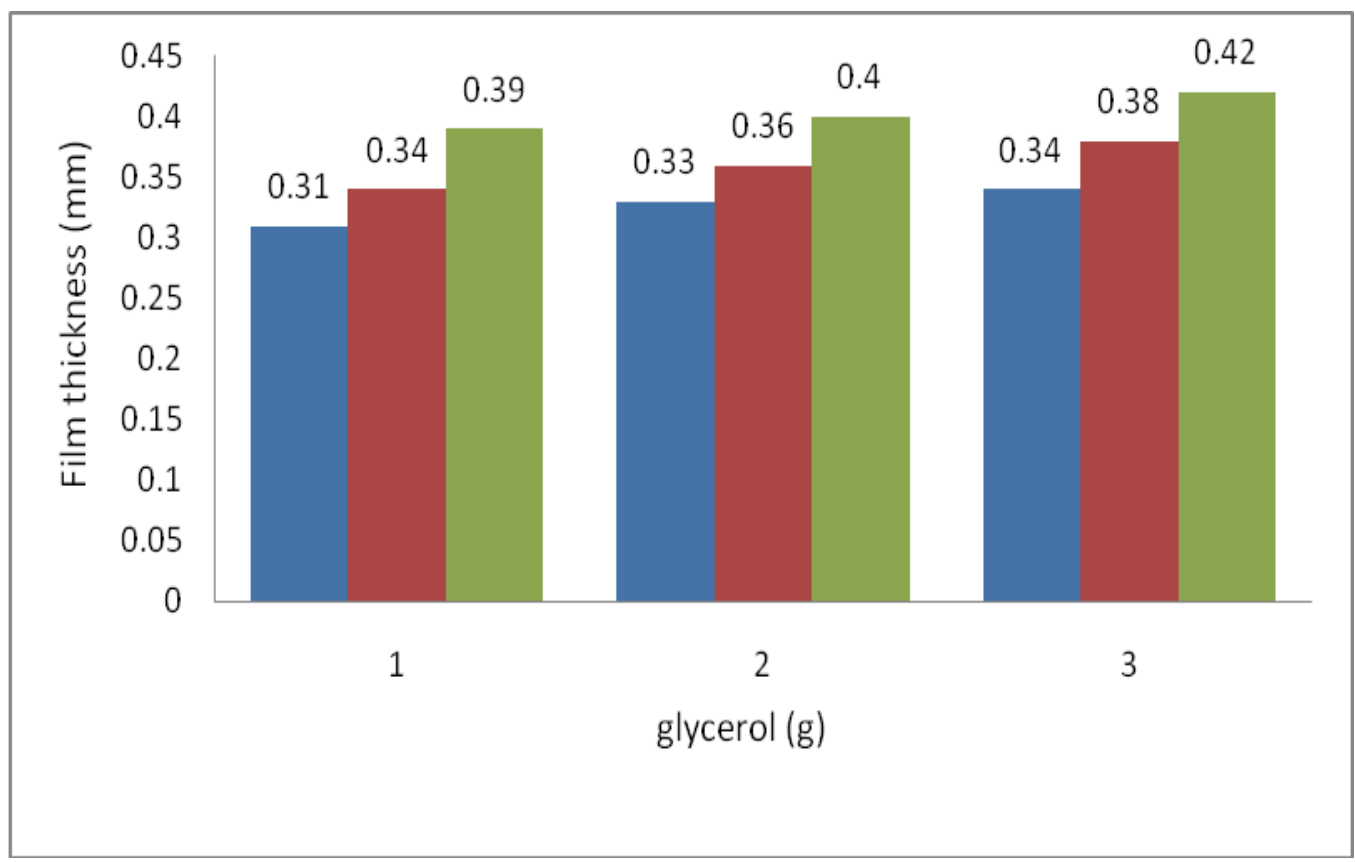


Fig.5 Effect glycerol and nanoparticles solution concentration on film \% transmittance

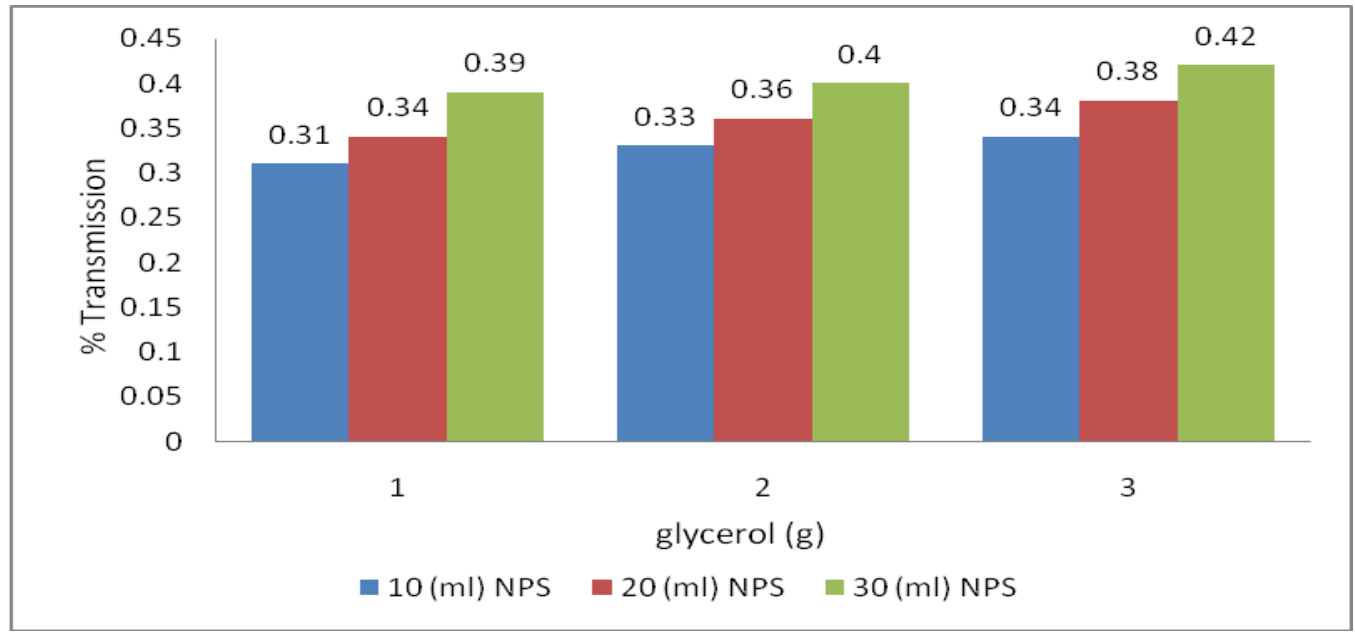

Fig.6 Effect of glycerol and nanoparticles solution concentration on tensile strength of film

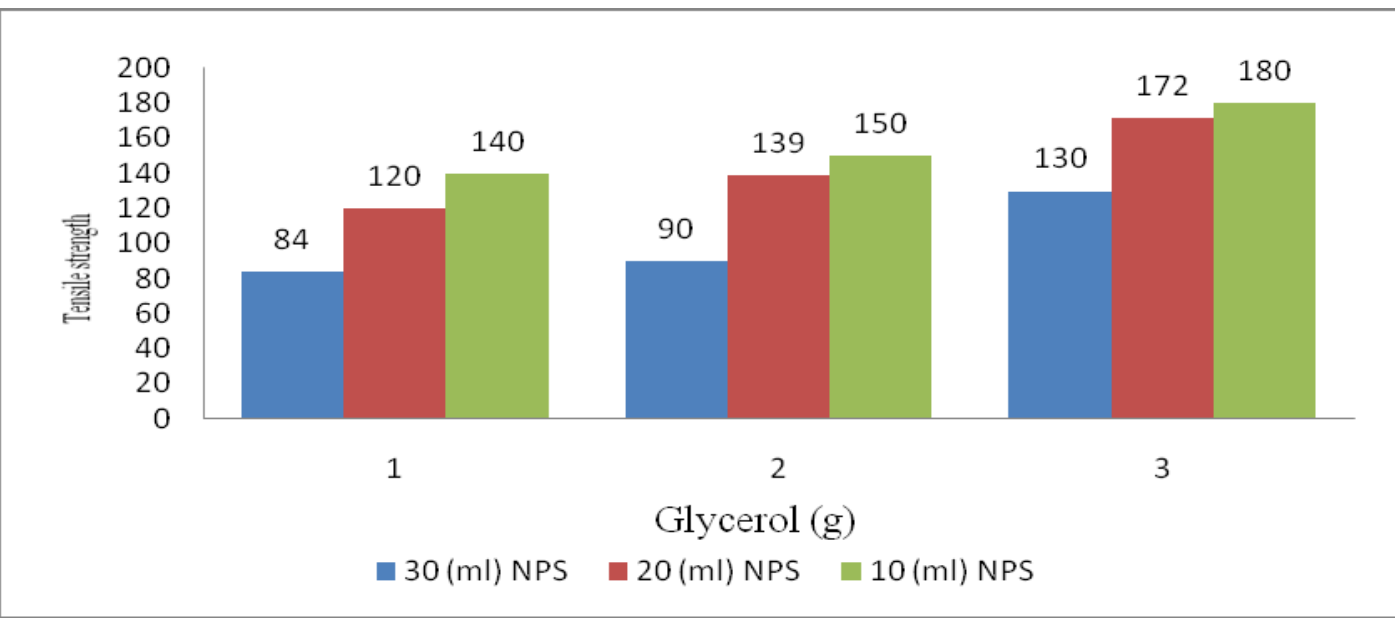

Fig.7 Effect of glycerol and nanoparticles solution concentration on \% elongation of film

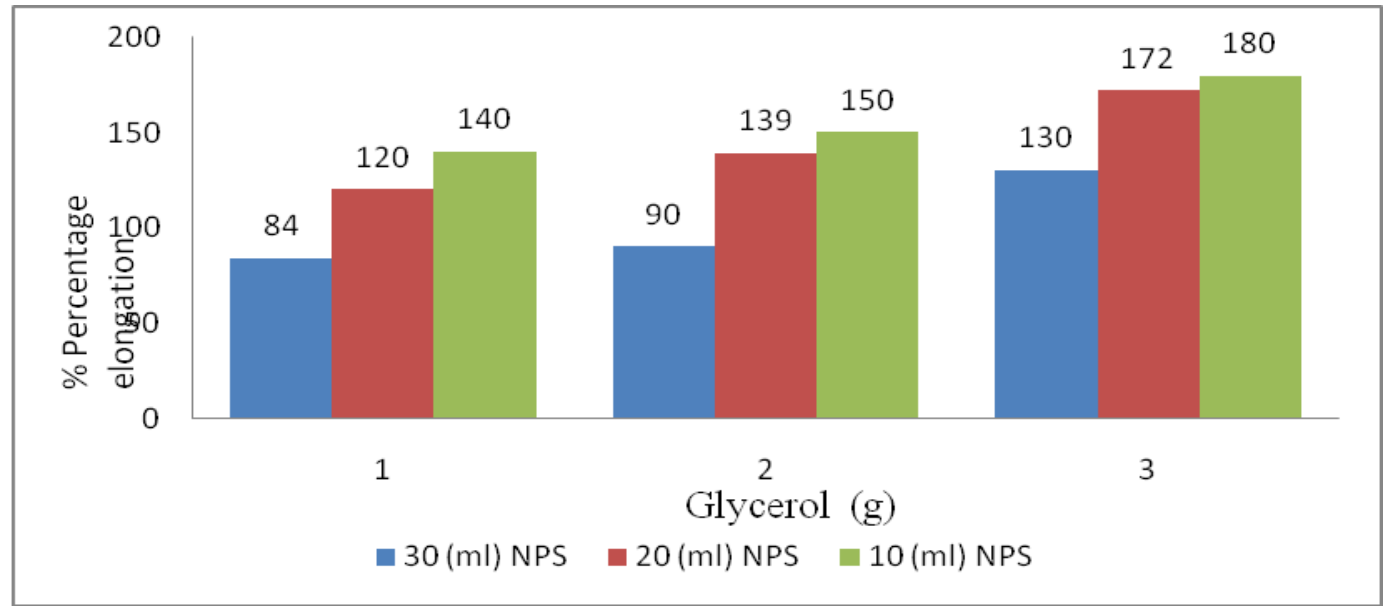


Fig.8 Effect of nanoparticles solution on \% WL of mangoes (1g glycerol formulations)

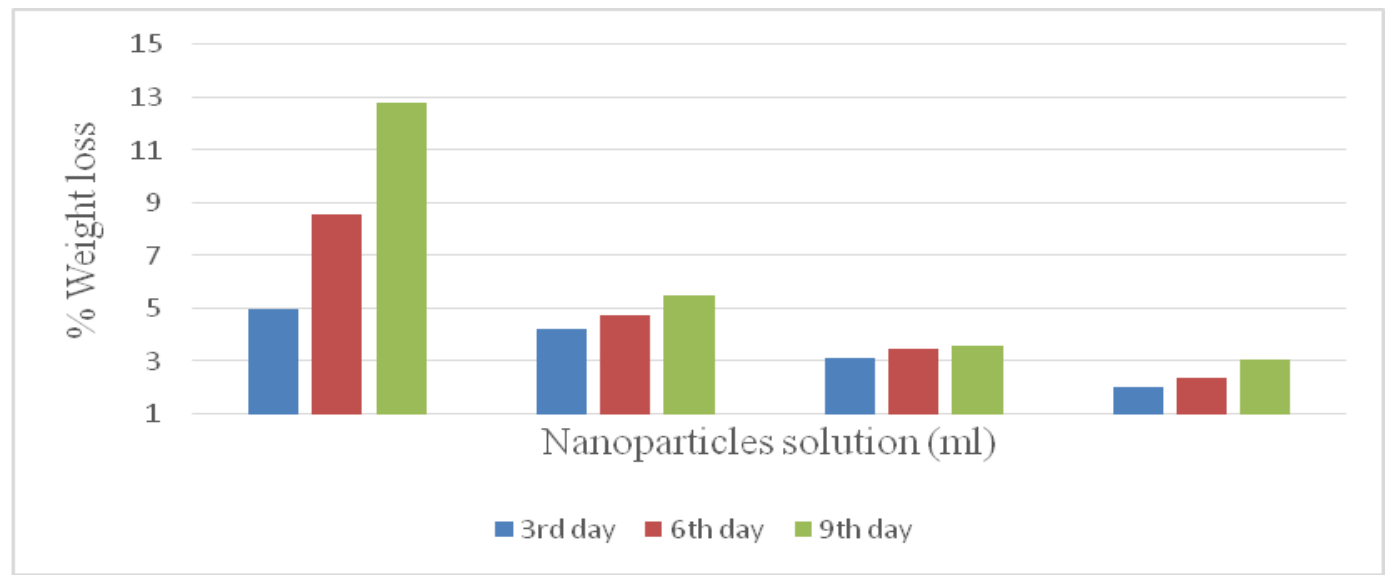

Fig.9 Effect of nanoparticles solution on \% WL of mangoes (2g glycerol formulation)

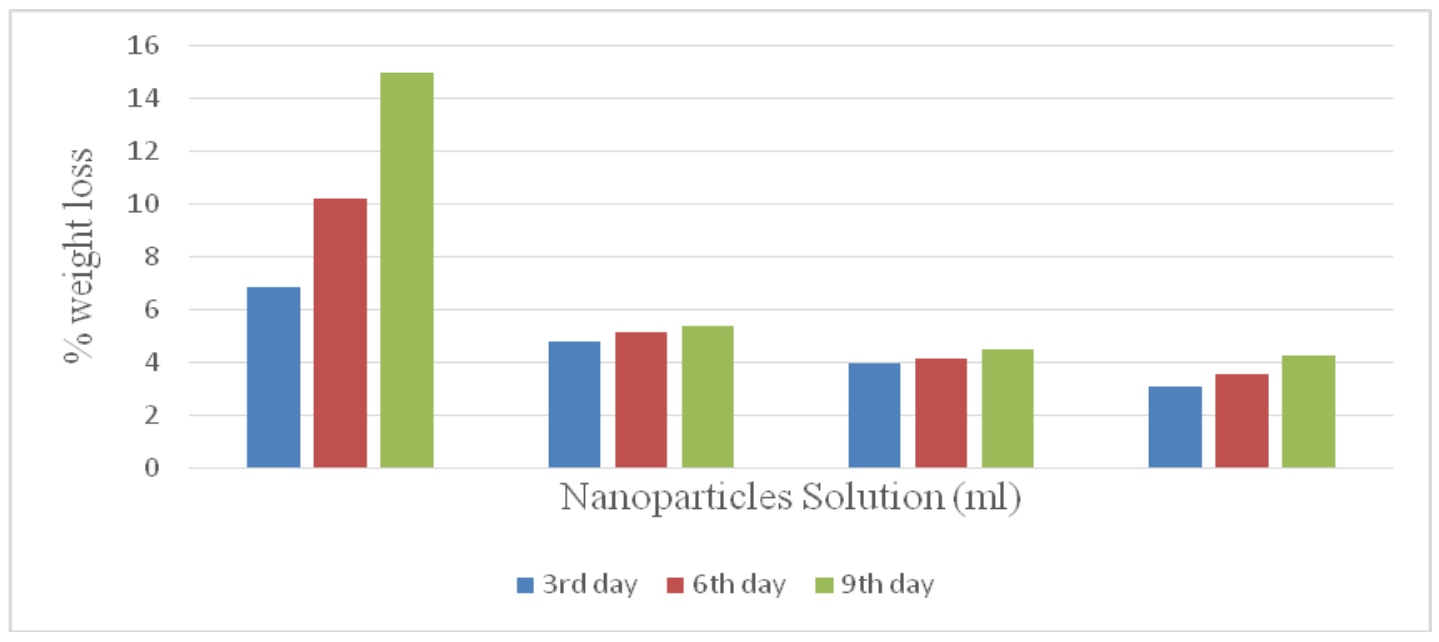

Fig.10 Effect of nanoparticles solution on \% WL of mango (3g glycerol formulation)

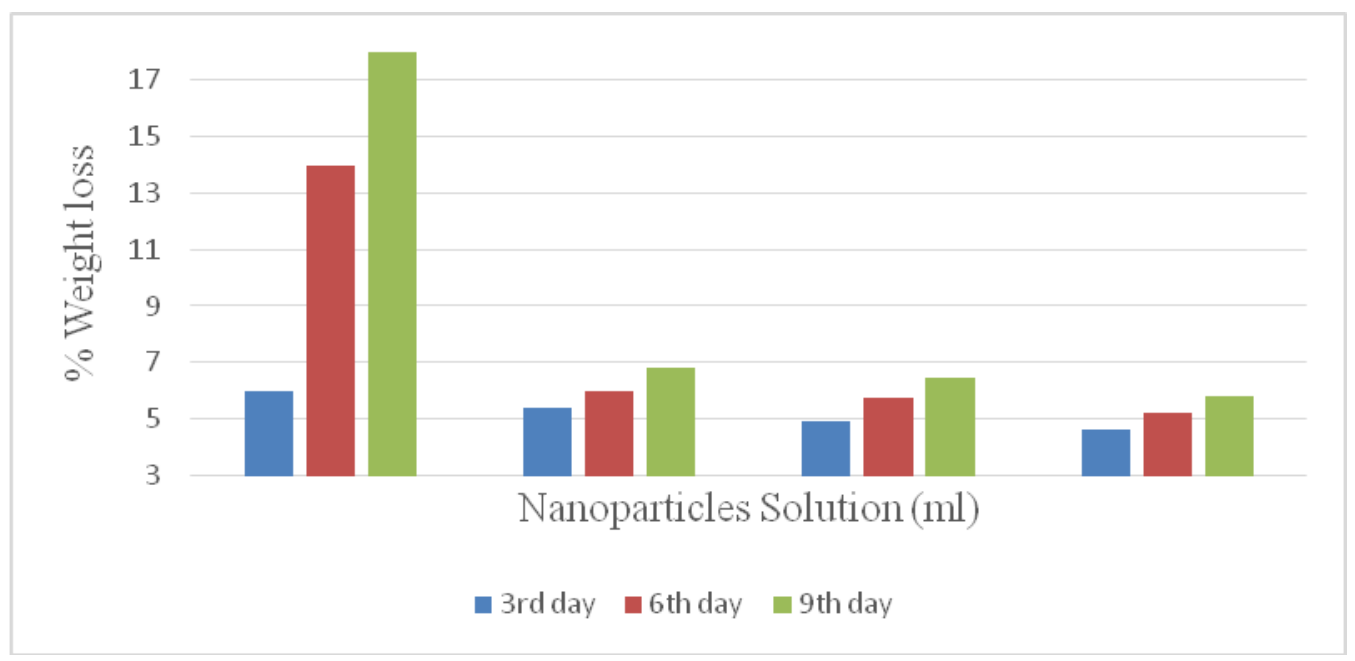


Fig.11 Effect of glycerol on \% WL of coated mangoes during storage

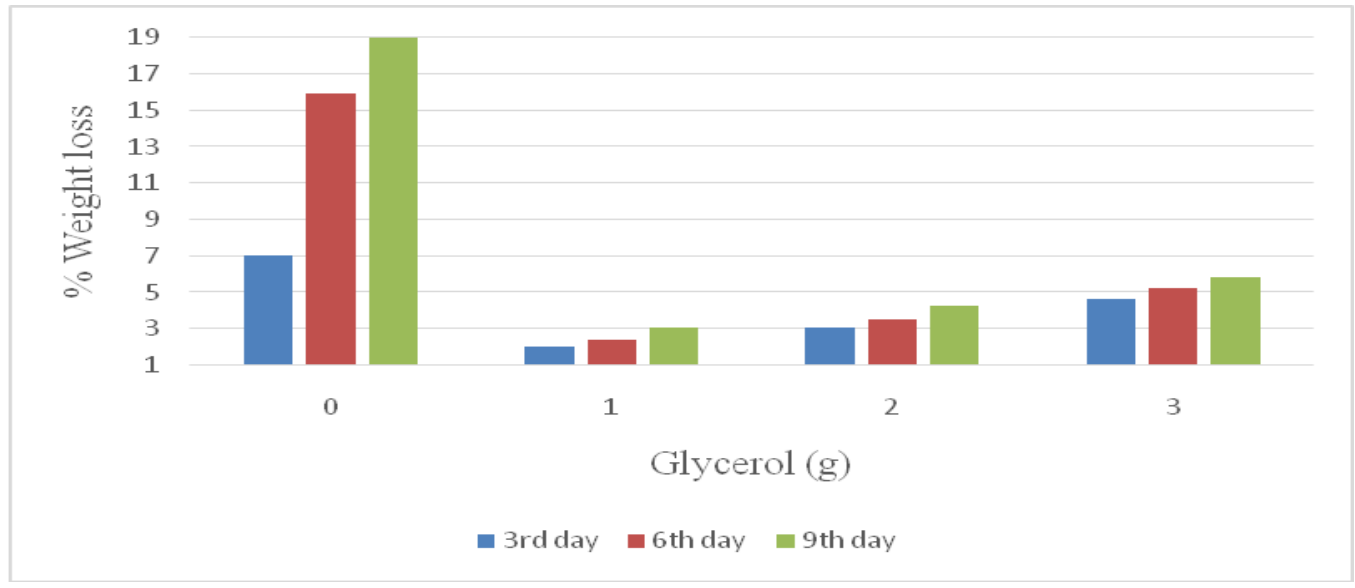

Fig.12 Effect of nanoparticles on \% TA of mango (1g glycerol formulation)

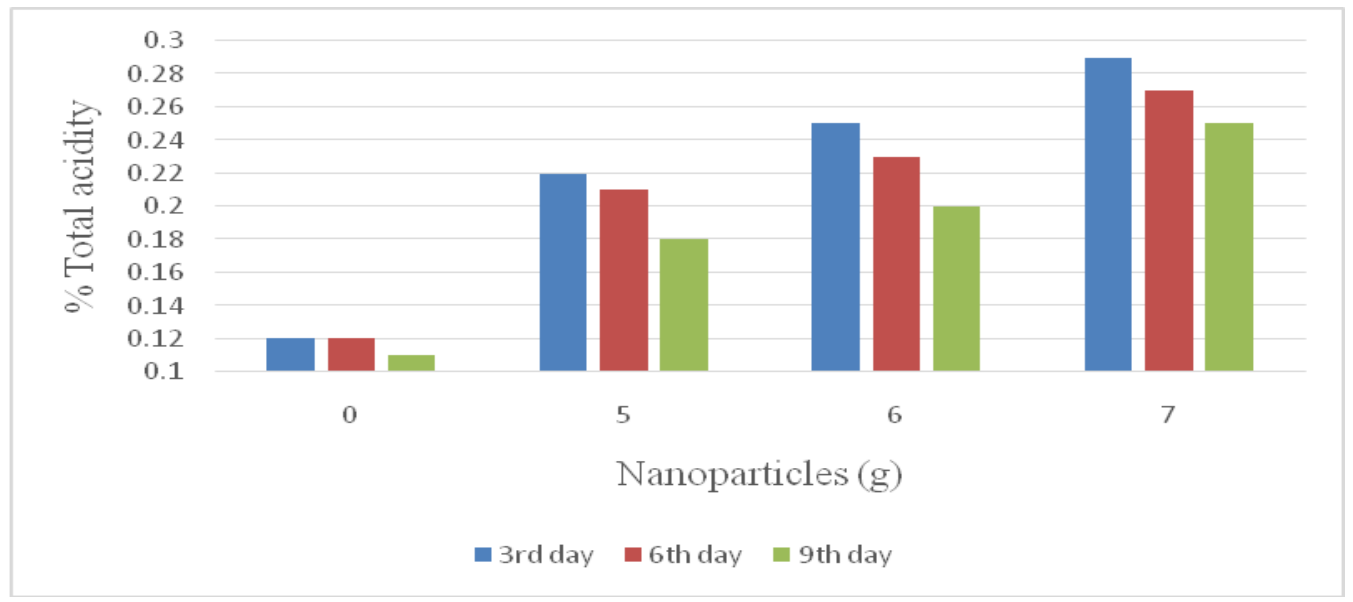

Fig.13 Effect of nanoparticles solution on \% TA of mango (2g glycerol formulation)

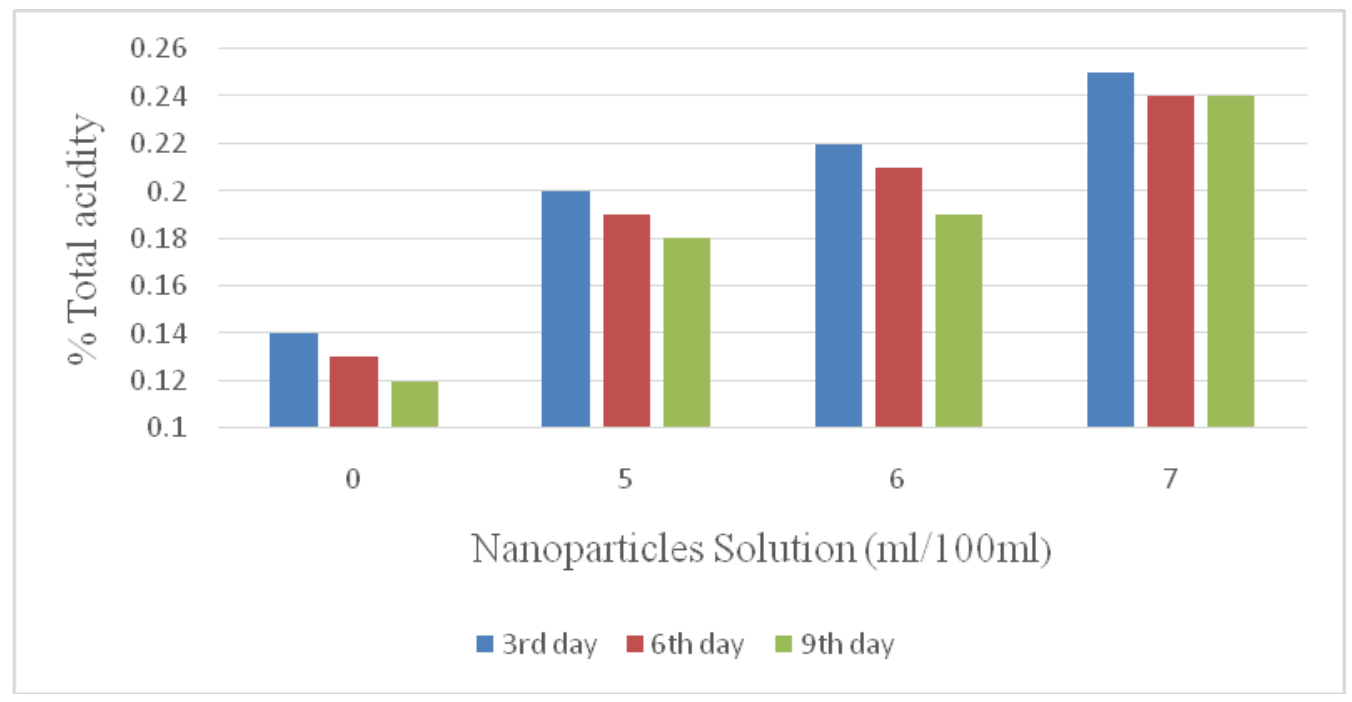


Fig.14 Effect of nanoparticles \% TA of mangoes (3g glycerol formulation)

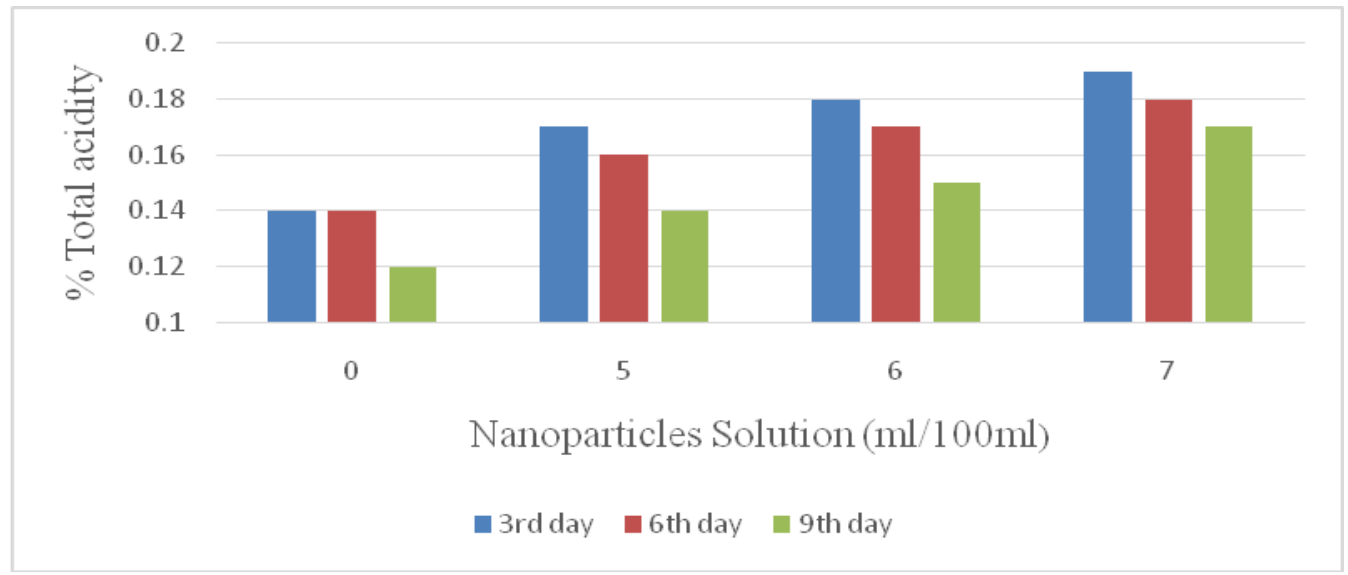

Fig.15 Effect of glycerol on \% total acidity of coated mango

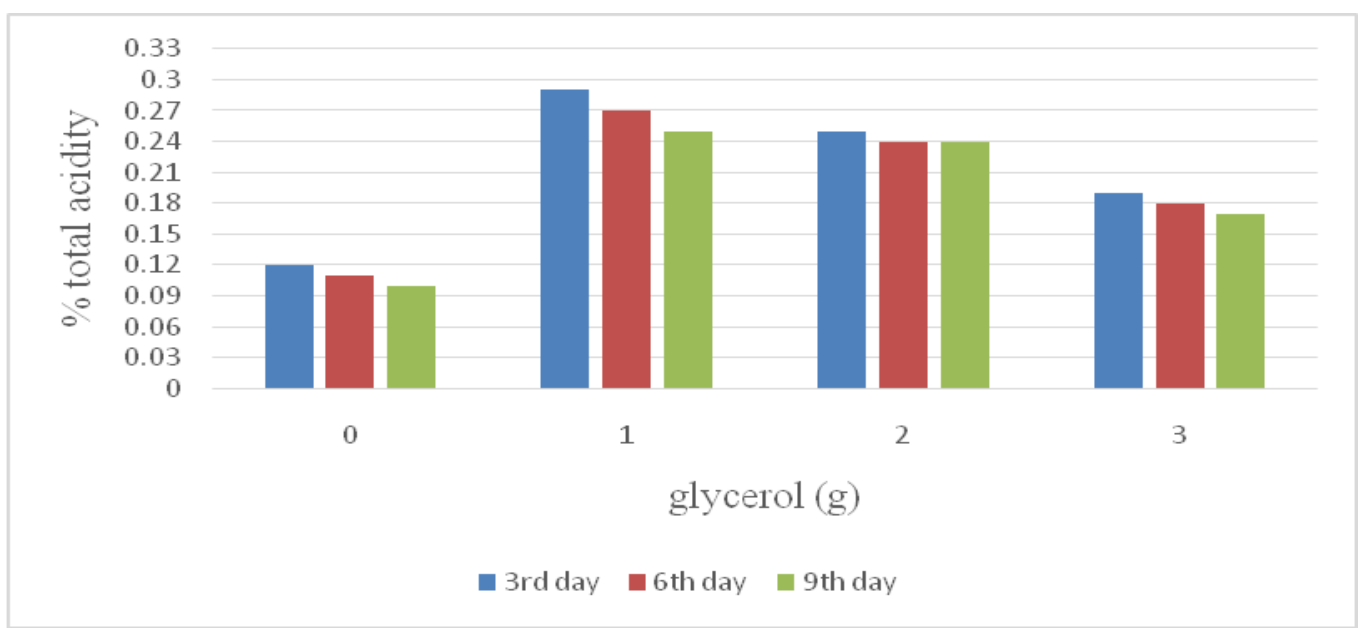

Fig.16 Effect of nanoparticles on ascorbic acid of mango (formulation $1 \mathrm{~g}$ glycerol)

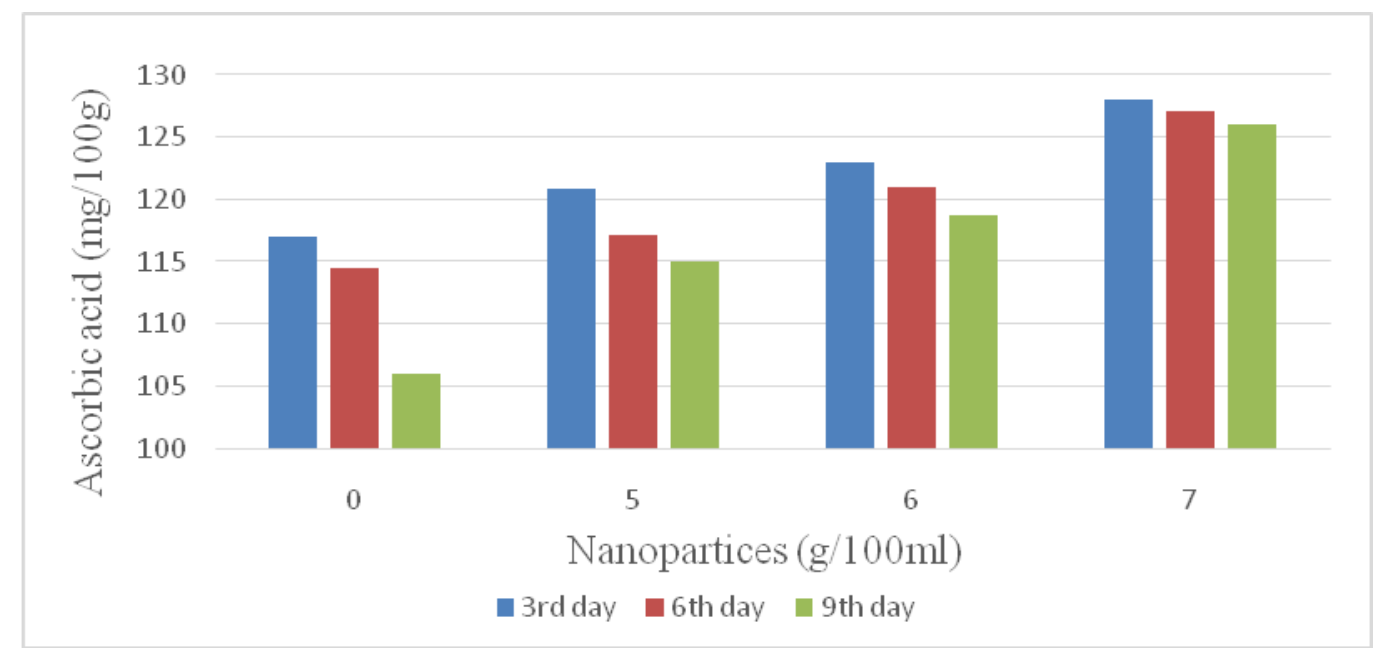


Fig.17 Effect of nanoparticles solution on ascorbic acid of mango (formulation $2 \mathrm{~g}$ glycerol)

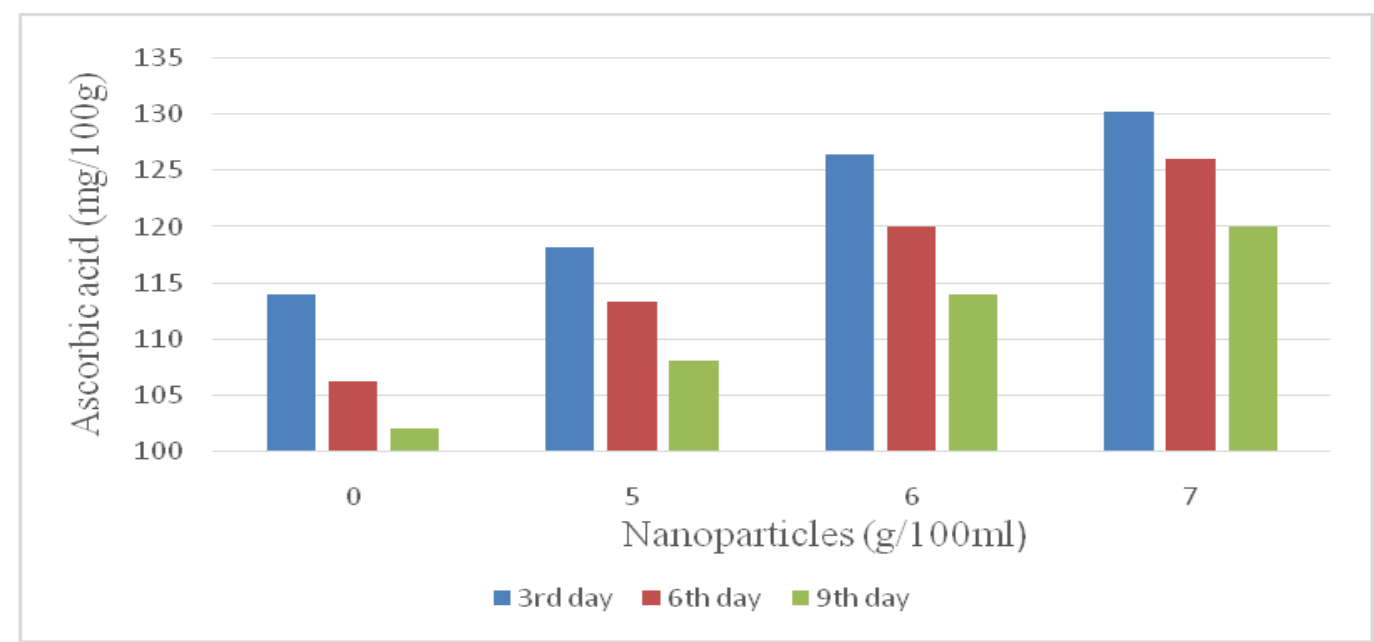

Fig.18 Effect of nanoparticles on ascorbic acid of mango (formulation $3 \mathrm{~g}$ glycerol)

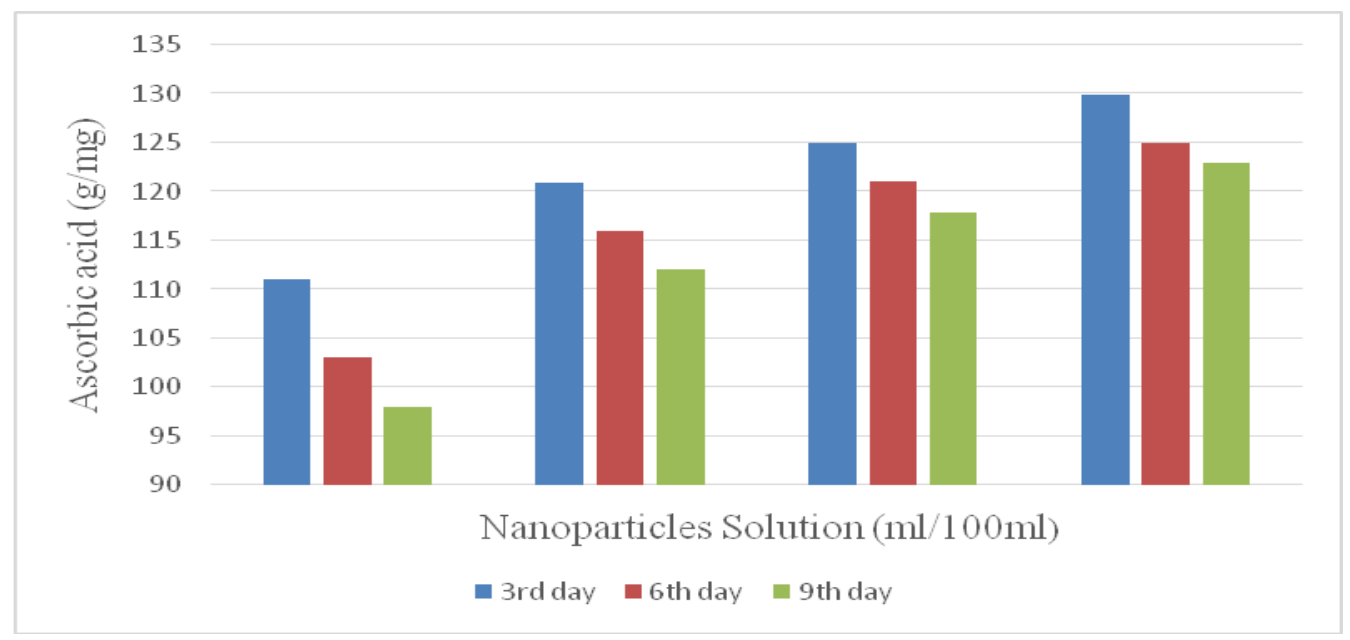

Fig.19 Effect of glycerol on ascorbic acid content of coated mango

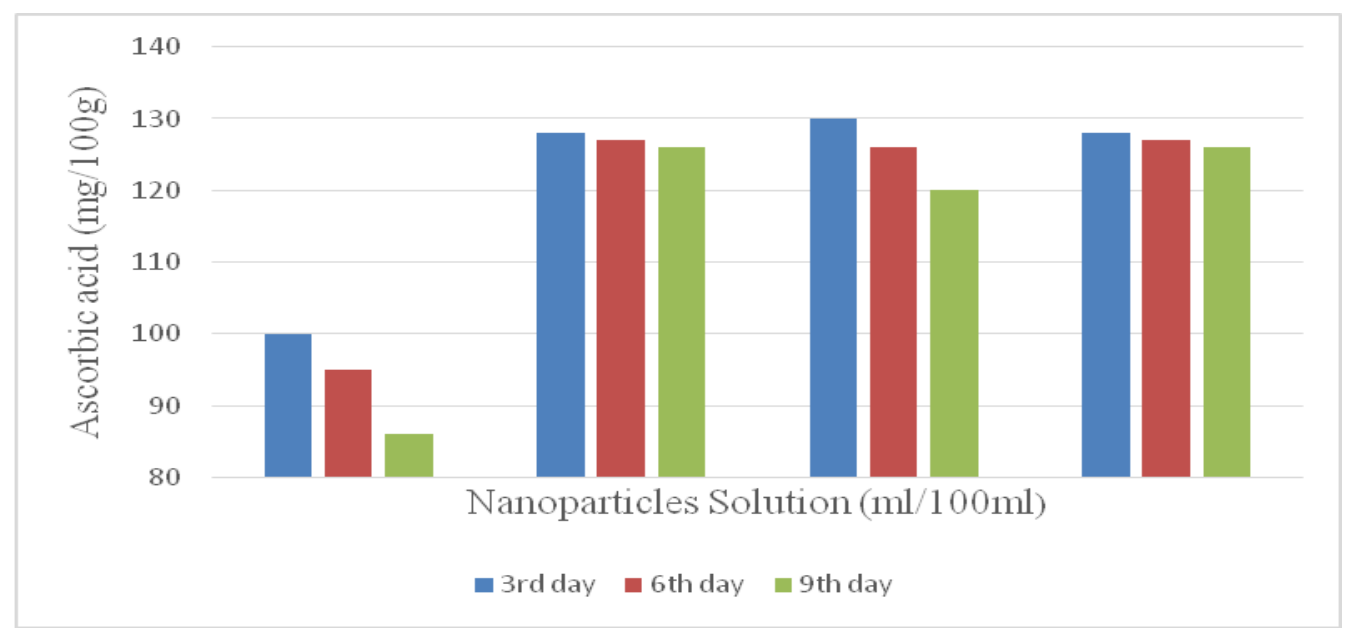


Fig.20 Effect of nanoparticles on TSS of mango (formulation 1g glycerol)

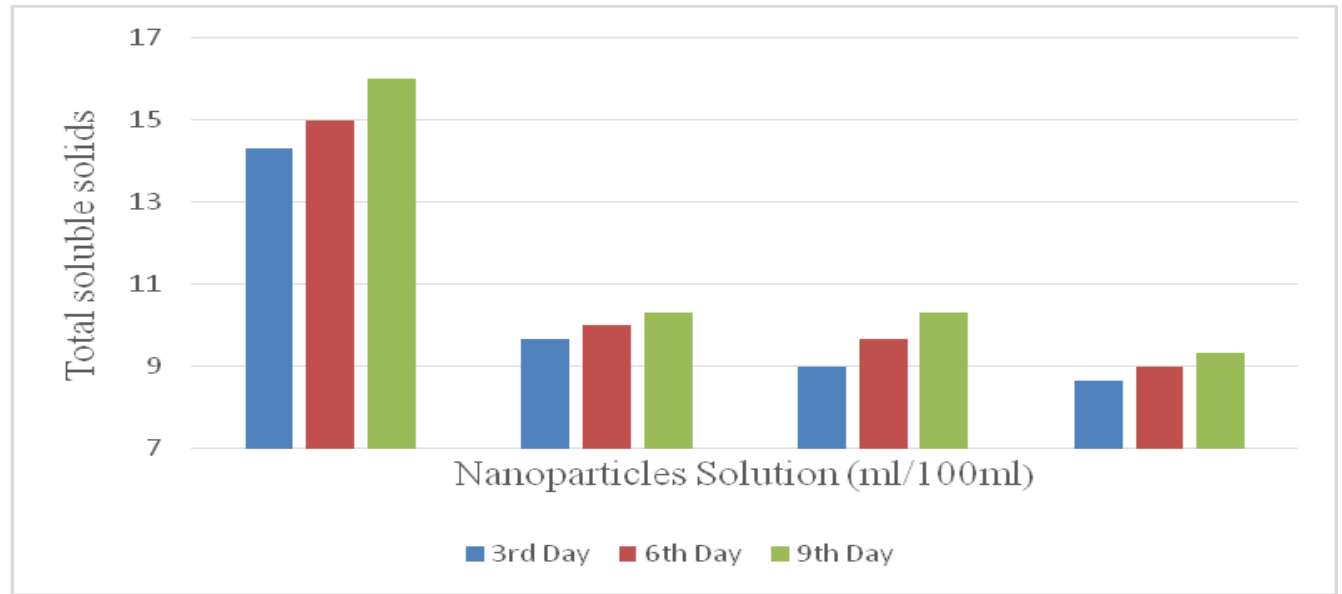

Fig.21 Effect of nanoparticles on TSS of mango (formulation $2 \mathrm{~g}$ glycerol)

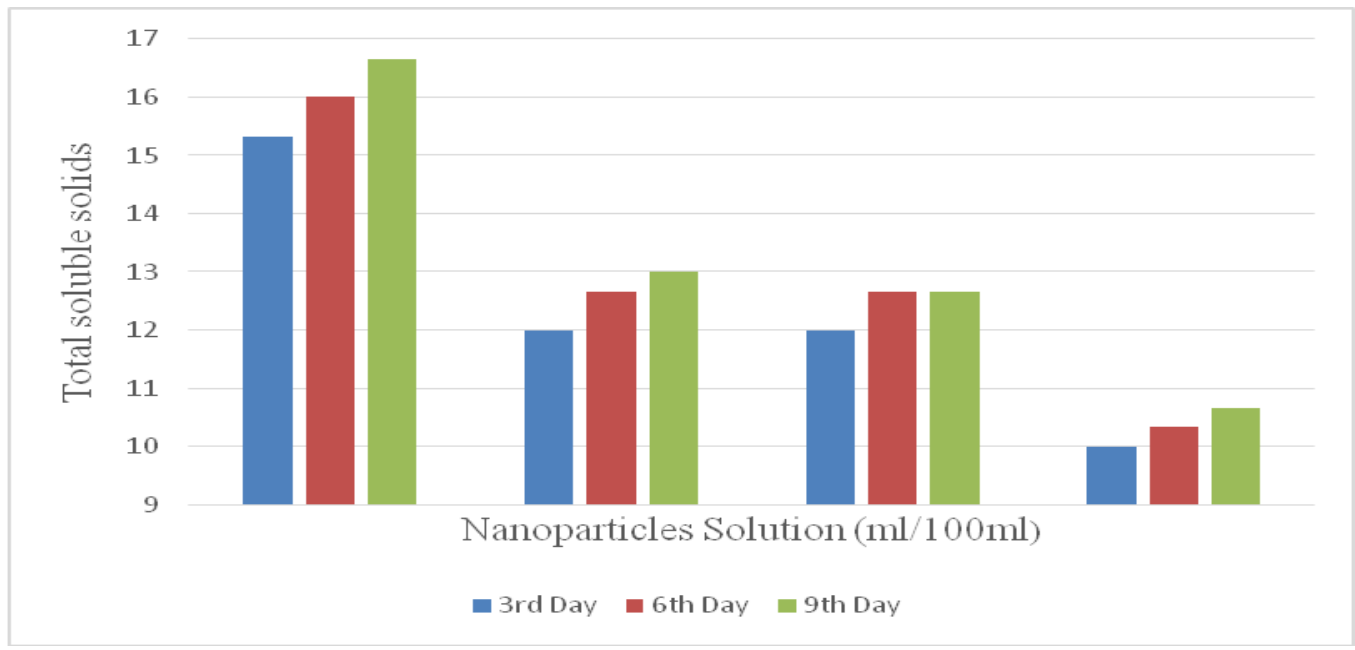

Fig.22 Effect of nanoprticles on TSS of mango (formulation $3 \mathrm{~g}$ glycerol)

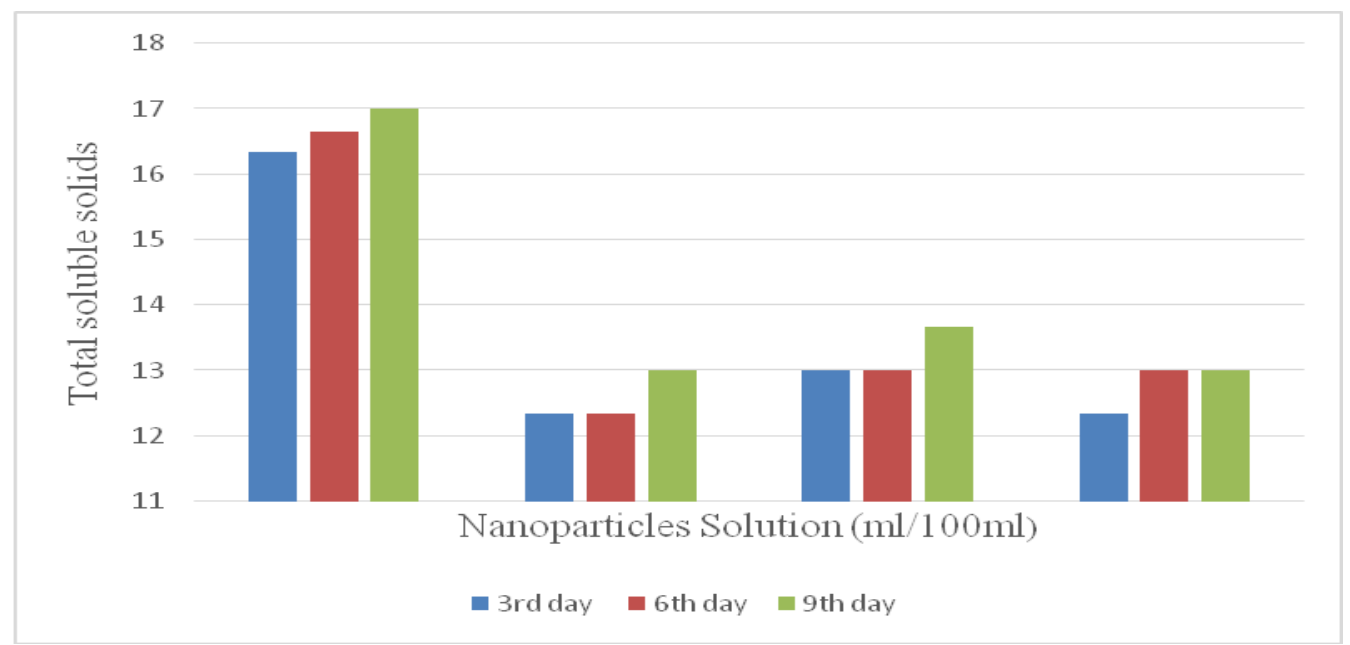


Fig.23 Effect of glycerol on TSS of coated mangoes

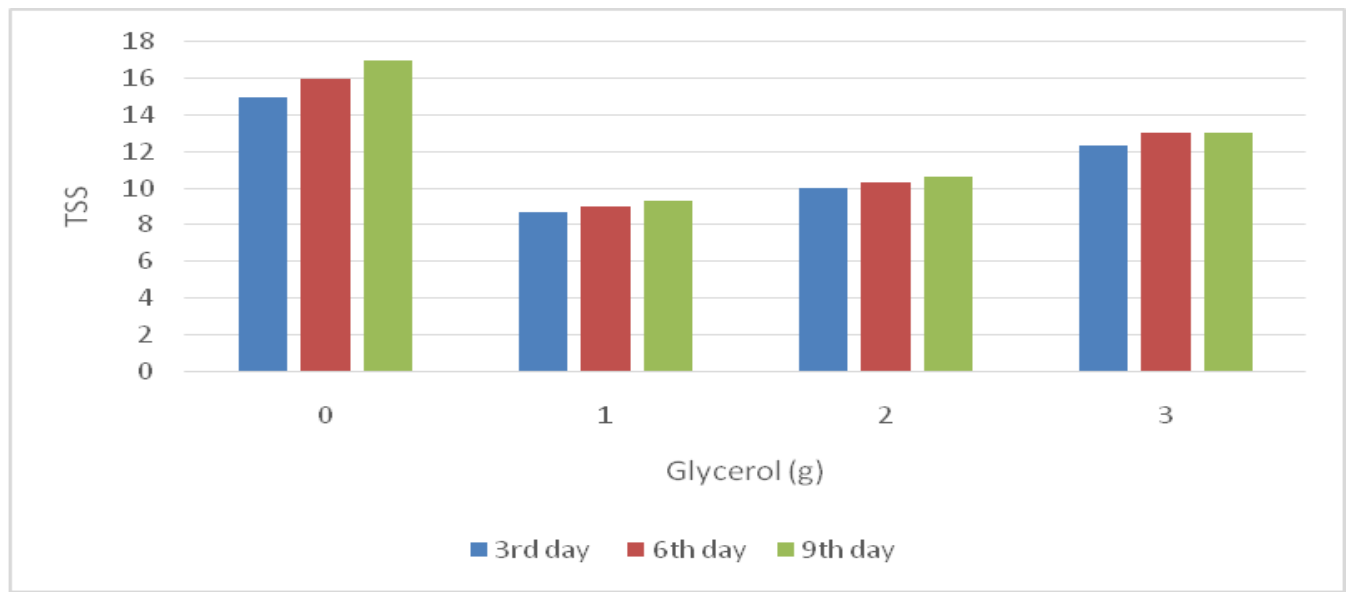

Fig.24 Effect of nanoparticles on $\mathrm{pH}$ of mango (formulation $1 \mathrm{~g}$ glycerol)

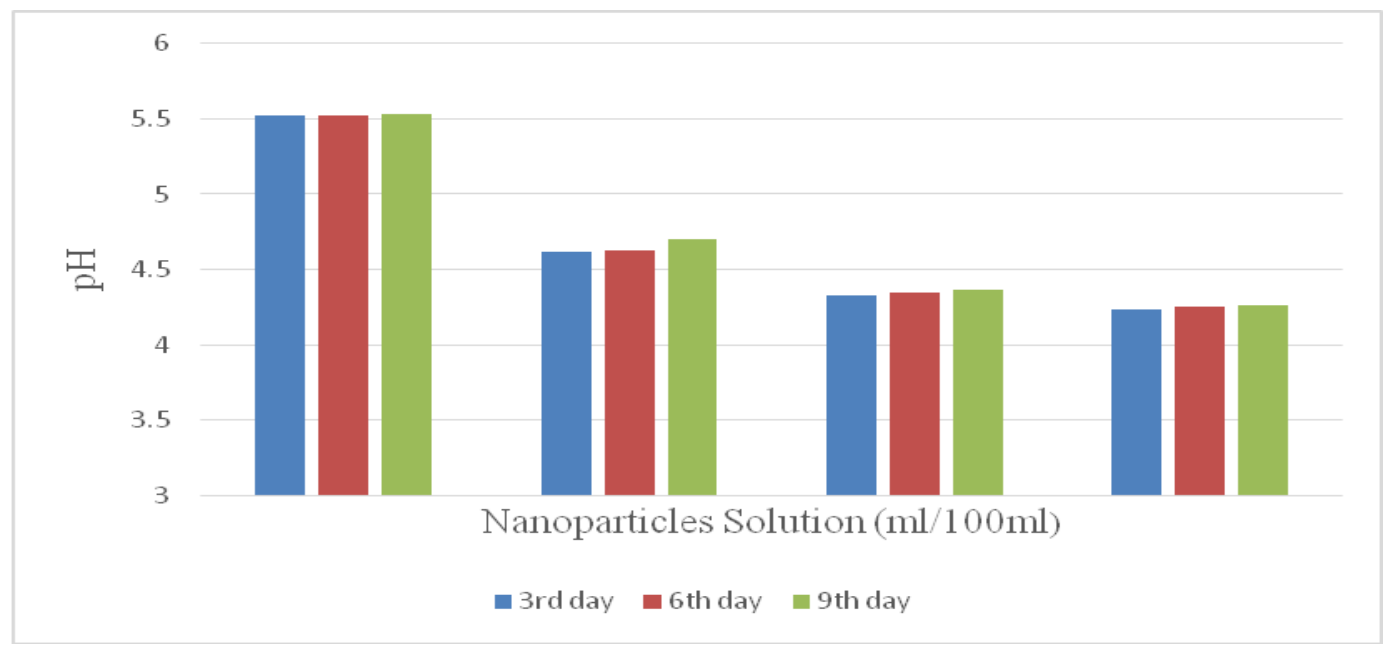

Fig.25 Effect of nanoparticles on $\mathrm{pH}$ of mango (formulation $2 \mathrm{~g}$ glycerol)

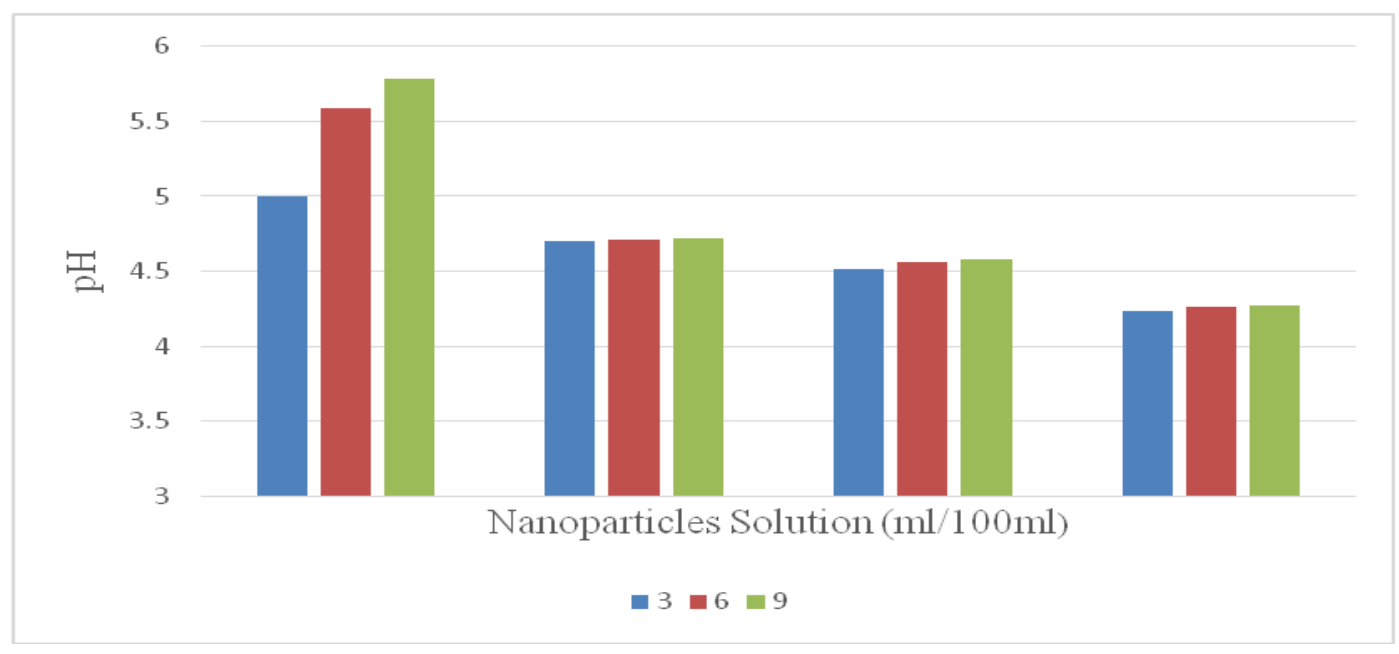


Fig.26 Effect of nanoparticles on pH of mango (formulation $3 \mathrm{~g}$ glycerol)

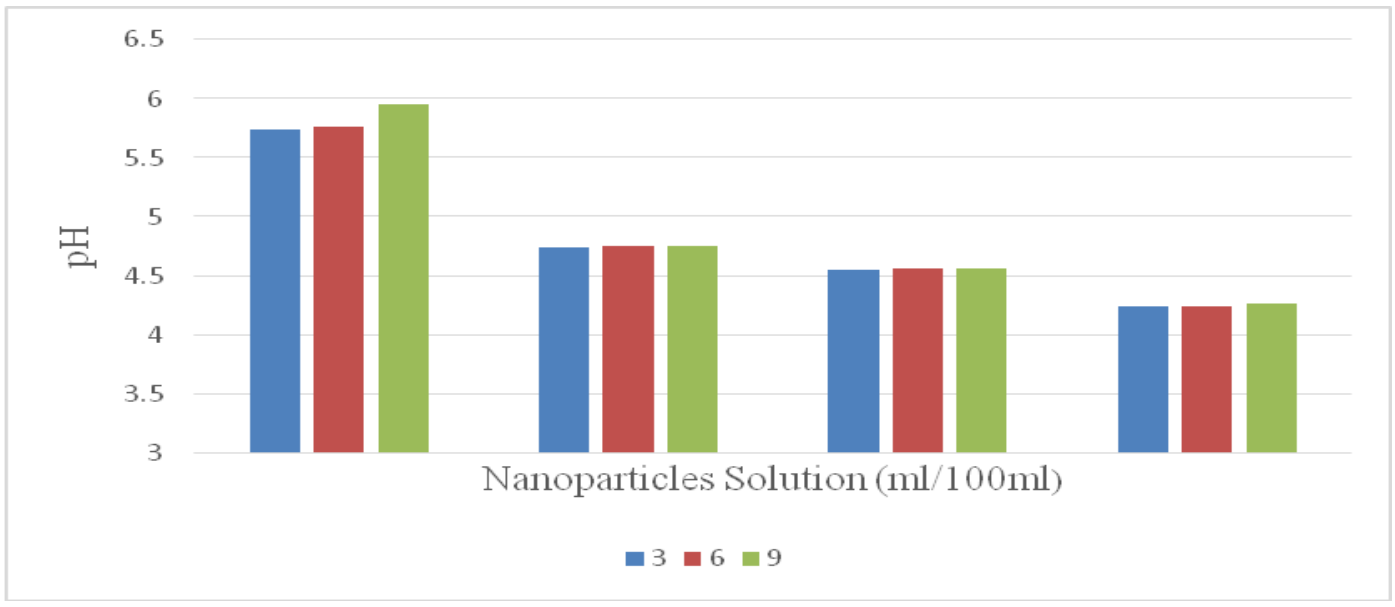

Fig.27 Effect of glycerol on pH of coated mango

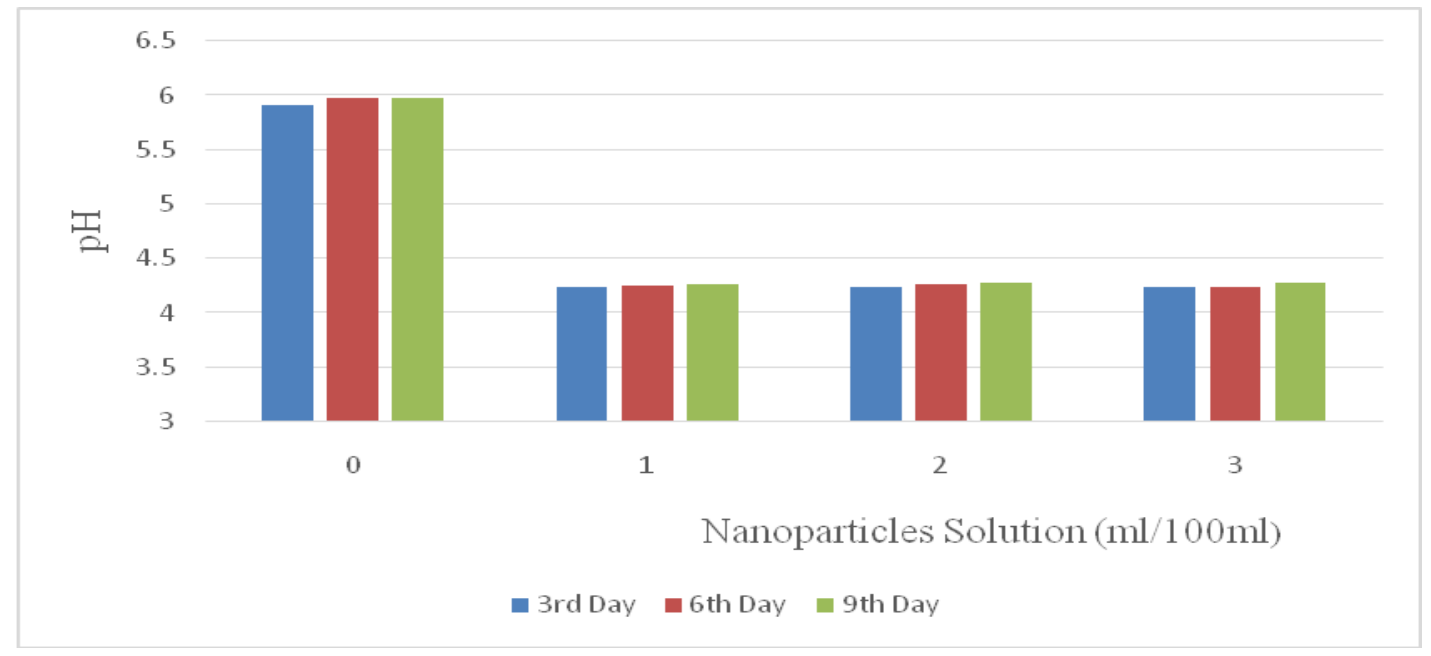

Fig.28 Edible coating on mangoes with different Glycerol (1g, 2g, 3g) solution and compared with Control

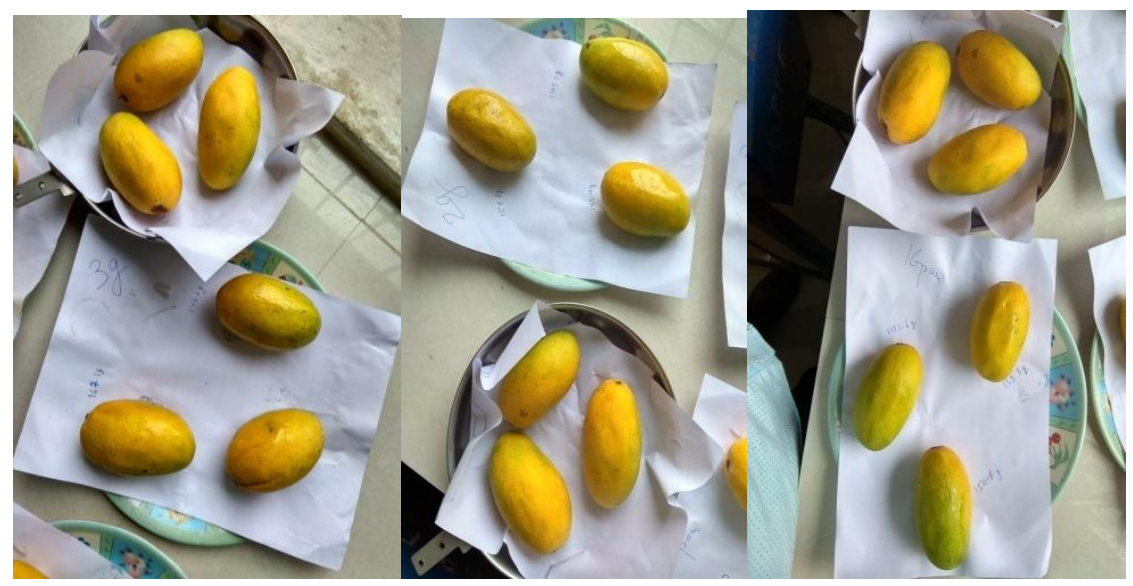


Fig.29 LDPE packaged material sealed on mangoes

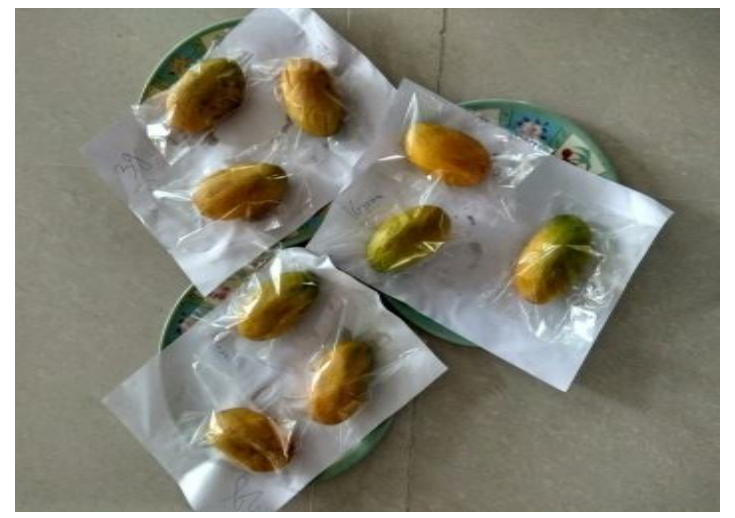

Fig.30 Mango coated with $\mathrm{T}_{(1,7)}$ with its control $\left(9^{\text {th }}\right.$ day of storage $)$

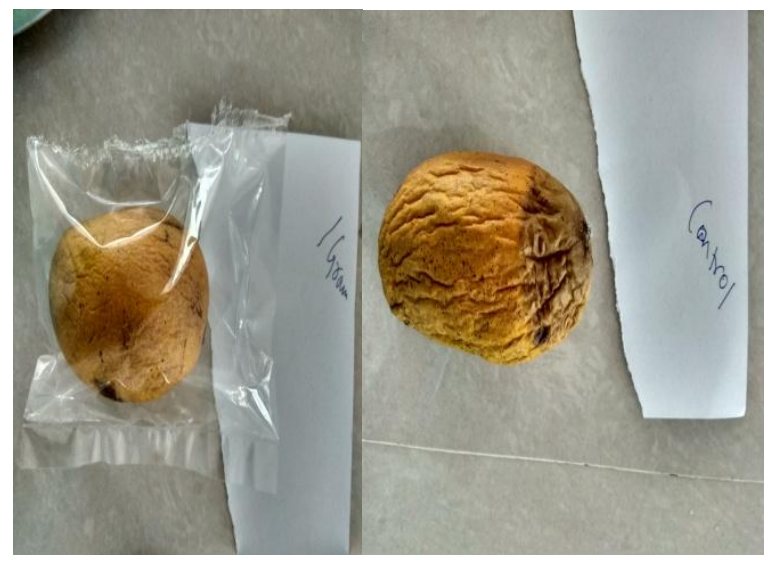

\section{Ascorbic acid content}

The ascorbic acid (mg/100g) in coated and control Mango samples were determined and it was found that it reduced during the storage. It reduced to a very low value in case of the control samples at the end of the storage. The ascorbic acid content in Mango fruit is in its maximum amount when they are at the mature green stage and then declines rapidly as they continue to ripe. During the storage the coated fruits did not ripe fast as compared to the control samples, the coatings on the fruit enabled them to preserve the ascorbic acid content to some extent.

Ascorbic acid is degraded by the action of oxygen, in the presence of oxygen ascorbic acid is converted to dehydroascorbic acid reported by Cocetta et al., (2014). As the fruit continue to respire during the storage period, carbohydrates break down to produce energy, and during this process oxygen is consumed and carbon dioxide, water and energy are evolved.

Here the glycerol concentration in the coating formulation had a significant effect on the ascorbic acid content of the fruit $(\mathrm{p}<0.05)$ as the glycerol concentration increased it retained less amount of ascorbic acid content, and the nanoparticles concentration also had a significant effect on it $(\mathrm{p}<0.05)$. It was observed that the ascorbic acid content in fruits retained in high quantity with increasing concentration of nanoparticles solution. This is due to the reason that the nanoparticles acts as an excellent barrier to oxygen, and less 
amount of glycerol helps in binding the formulation intact to the surface of the fruit, thus preserving ascorbic acid content in Mangoes. The results are in line with the findings of Radi et al., (2017), in this work they formulated composite edible coating containing aloe vera gel, nanoparticles solution, green tea and black tea extracts for fresh peeled oranges. It was observed here that the nanoparticles solution acted as barrier to oxygen and its incorporation into the coatings enabled in preserving ascorbic acid content of the fruits during storage.

\section{Total soluble solids (TSS)}

As the fruits continue to ripe the total soluble solid content in them increases. In many of the fruits including mangoes when they are ripe sugar is one of the major soluble solid components reported by Cano et al., (1997).

In this study it was observed that the TSS of both coated and control mangoes increased with increase in storage period. TSS of control fruits increased at a higher rate, but the mangoes with composite edible coating showed slow rate of increase in the values of TSS.

TSS increases during ripening, this is due to starch hydrolysis and pectin degradation The glycerol concentration in the coating formulation significantly affected the TSS of coated mangoes $(\mathrm{p}<0.05)$. TSS value increased with increasing glycerol concentration. Glycerol is used as the plasticizer here, at low concentration it would have enabled in increasing the intermolecular forces between the components in the coating formulation and thus lowering the respiration rate and hence decreasing the TSS. The concentration of nanoparticles solution and aloe vera in the coating also showed a significant effect on the TSS of mangoes. As its concentration increased it helped in maintaining a low TSS of the fruit, as it would have enabled lowering respiration being an oxygen barrier component. The results of the study were in line with the results of Gol and Rao (2013) which included coating of mango fruit and showed similar trend of result.

\section{pH of coated mangoes during storage}

$\mathrm{pH}$ of both control and coated mangoes increased very slightly during the storage period. $\mathrm{pH}$ of fruits is associated with ripening of fruits. During storage as the fruit respire the ripening process increases and hence $\mathrm{pH}$ of the fruit pulp increases. The concentration of glycerol and nanoparticles solution with aloe vera a had significant effect on the $\mathrm{pH}$ of the fruit $(\mathrm{p}<0.05)$ as the concentration of nanoparticles solution increased, the $\mathrm{pH}$ decreased, this is because of the fact that nanoparticles solution acts as an oxygen barrier (discussed earlier in this chapter) and hence increase in nanoparticles solution concentration would have decreased the respiration and ripening process of the coated fruit, as a result decreased the $\mathrm{pH}$ of the fruit.

The results are in line with the findings of Gol and Rao (2013), the work involved coating of mango with composite edible coating comprising of gelatin, zien and glycerol.

The edible films with different concentration of $10 \mathrm{mg}$ nanoparticles with water $(10 \mathrm{ml}$, $20 \mathrm{ml}, 30 \mathrm{ml}$ ) and different concentration of glycerol $(1 \mathrm{~g}, 2 \mathrm{~g}$ and $3 \mathrm{~g})$ in of aloe vera gel $(90 \mathrm{ml}, 80 \mathrm{ml}, 70 \mathrm{ml})$ solution were prepared, and the properties of the developed films were tested for evaluating their functionality. The effect of concentration of glycerol on each property of the film and the effect of concentration of nanoparticles solution with aloe vera on each film property was evaluate The thickness of the films were measured and 
it was observed that thickness increased with increasing concentration of both glycerol and nanoparticles solution. The film with highest thickness was $\mathrm{T}_{(3,9)}$ with $0.42 \mathrm{~mm}$, and the thinnest film produced was $\mathrm{T}_{(1,7)} 0.31 \mathrm{~mm}$. $\mathrm{T}_{(3,9)}$ had the highest amount of glycerol $(3 \mathrm{~g})$ and nanoparticles solution (10ml) combination whereas $T_{(1,7)}$ had the lowest amount of the components, $1 \mathrm{~g}$ glycerol and $30 \mathrm{~g}$ nanoparticles solution. The percentage transparency increased with increase in the concentration of both glycerol and nanoparticles solution. $\mathrm{T}_{(3,7)}$ had the highest transparency of $48.3 \%$ and lowest transmittance was shown by the film $\mathrm{T}_{(1,5)}$ which had $27.4 \%$ transmittance. Both nanoparticles solution and glycerol concentration significantly affected the mechanical properties of the developed film. The tensile strength was lowest and \% elongation was highest in the film $\mathrm{T}_{(3,7)}$, tensile strength was $7.37 \mathrm{MPa}$ and $180 \%$ respectively. Sealability of the films were also affected by the concentration of nanoparticles solution and glycerol, the observations showed that a formulation with high concentration of aloe vera will be difficult to seal.

Same film formulations were then applied as coating to preserve Mango fruits. The fruits were coated and stored at room temperature for 9 days. All the quality parameters were tested at $3^{\text {rd }}, 6^{\text {th }}$ and $9^{\text {th }}$ day of storage and the effect of concentration of glycerol on each quality parameter of the coated fruit and the effect of concentration of nanoparticles solution on each quality parameter of the coated fruit was evaluated during the storage. Weight loss was minimum with $3.08 \%$ for Coating $\mathrm{T}_{(1,7)}$ maintaining the quality of the fruit on the $9^{\text {th }}$ day of storage. Thus glycerol and nanoparticles solution had significant effect on \% weight loss of mango. As the nanoparticles solution concentration in coating increased and glycerol concentration decreased it resulted in much low value of fruit weight loss as compared to its control sample with $12.79 \%$ weight loss.

Percentage total acidity was also retained in higher amounts $(0.25 \%)$ in fruits with Coating $\mathrm{T}_{(1,7)}$ when compared to its control $(0.1 \% \mathrm{TA})$ on the $9^{\text {th }}$ day of storage.

Ascorbic acid was also retained in highest quantity in mangoes coated with $\mathrm{T}_{(1,7)}$ about $126 \mathrm{mg} / 100 \mathrm{~g}$ of sample when compared to its control which had a very low ascorbic acid content of $105.98 \mathrm{mg} / 100 \mathrm{~g}$ and thus maintaining the quality of the fruit.

Similarly $\mathrm{pH}$ and TSS of the coated mango pulp was maintained at lowest values for

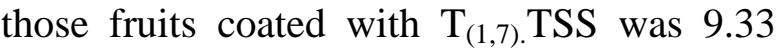
for $\mathrm{T}_{(1,7)}$ coated samples and was 19 for control samples. $\mathrm{pH}$ was 4.26 for $\mathrm{T}_{(1,7)}$ coated fruits and 5.98 for control fruits.

All the composite edible film formulations produced stand alone films and the best film formulation that can be used as a primary packaging material is $\mathrm{T}_{(3,7)}$. And all the formulations when applied as coatings on the fruits helped in maintaining the quality of mango fruit upto 9 days, on the basis of the analysis of quality parameters of the fruit it can be concluded $T_{(1,7)}$ coating is the best formulation suitable if it is to be used for coating of fruits and vegetables.

The aim of the present work was to develop a composite edible film with good mechanical strength and optical properties that can be used as a primary food packaging material, thus reducing the use of non-biodegradable packaging materials. The films with less concentration of glycerol and nanoparticles solution were more transparent, had good mechanical stability and thickness. The same formulations of films when applied on mango fruits, aimed at maintaining the quality of the 
fruit upto 9 days of storage at room temperature. Coating aloe vera gel alone has maintained the quality of several fruits, however all those treatments needed an additional packaging material for support. Development of an edible coating which alone has the capability of maintaining the quality of the packed commodity is a great achievement. At the end it can be concluded that the nanocomposite edible films and coatings are a simple, environmentally friendly, and relatively in expensive technology that can extend the shelf life of Fresh mangoes when stored at room temperature.

\section{References}

Altenhofen, M., Krause, A., and Guenter, T. (2009). Alginate and pectin composite films cross linked with Cap2 ions: effect of the plasticizer concentration. $J$. Carbohydrate Polymers, 77(4), 736-742.

Arrieta, M.P., Peltzer, M.A., López, J., Garrigós, M.D.C., Valente, A.J.M., Jiménez (2014), A. Functional properties of sodium and calcium caseinate antimicrobial active films containing carvacrol. J. Food Eng., 121, 94-101.

Banks N.H. (1984), Internal atmosphere modification in Pro-Long coated apples. ActaHort. 157, 105-112.

Biscarat, J., Charmette, C., Sanchez, J., PochatBohatier, (2015). C. Development of a new family of food packaging bioplastics from cross-linked gelatin based films. Can. J. Chem. Eng., 93, 176-182.

Cano, M.P., Ancos, B., Matallana, M.C., Chmara, M., Regleroc, G. and Tabera, J. (1997). Differences among Spanish and Latin-American banana cultivars: morphological, chemical and sensory characteristics. Food Chemistry, 59(3), 411-419.

Chang, P., Chea, P. B., and Seow, C. C. (2000). Plasticizing-antiplasticizing effects of water on physical properties of cassava starch films in the glassy state. Journal of
Food Science, 65(3), 445-451.

Charles, L., Wilson, A., Ghaouth, E., Chalutz, E., Droby, S., Stevens, C., John, Y. L., Khan, V. and Joseph, A. (1994). Potential of induced resistance to control postharvest diseases of fruits and vegetables. Plant Disease 78(9), 837842.

Cocetta. G, Baldassarre. V, Spinardi. A, Ferrante, A, (2014). Effect of cutting on ascorbic acid oxidation and recycling in fresh-cut baby spinach (Spinacia oleracea L.) leaves. Postharvest Biology and Technology, 88, 8-16.

Gol B. Neeta and Rao Ramana T.V, (2013). Influence of zein and gelatin coatings on the postharvest quality and shelf life extension of mango (Mangifera indica L.) Fruits, EDP sciences vol. 69, p. 101-115.

Habeeb F., Shakir E., Bradbury F., Cameron P. (2007). Screening methods used to determine the anti-microbial properties of Aloe vera inner gel. Methods, 42, 315320.

Hamman J.H. (2008). Composition and applications of aloe vera leaf gel. Molecules.13, 1599-1616.

Karbowiak, T., Debeaufort, F., Champion, D., and Voilley, A. (2006). Wetting properties at the surface of iotacarrageenan-based edible films. Journal of Colloid and Interface Science, 294, 400-410.

Lone M.A, Dinisha M, Arti D, Safina RC (2009). Anti inflammatory and antimicrobial activity of anthraquinone isolated from Aloe vera (Liliaceae). Asian journal of chemistry, 21, 1807-1811.

Lopez-Rubio A., Almenar E., HernandezMunoz P., Lagaron J.M., Catala R., Gavara R., (2004). Overview of active polymer-based packaging technologies for food applications. Food Rev. Int.., 20, 357-387.

Malhotra, B., Keshwani, A., Kharkwal, H. (2015). Natural polymer based cling films for food packaging. Int. J. Pharm. Pharm. Sci., 7, 10-18.

Mari, M., Francesco, A. D. and Bertolini, P. 
(2014). Control of fruit postharvest diseases: old issues and innovative approaches. Stewart Postharvest Review, $10(1), 1-4$.

Martinez-Romero D, Alburquerque N, Valverde JM, Guillen F, Castillo S, Valero D, Serano M, (2006). Postharvest sweet cherry quality and safety maintenance by aloe vera treatment: a new edible coating. Postharvest boil tech, 39, 93-100.

Maughan RG (1984) Methods to increase colour fastness of stabilized aloe vera. US Patent, 4, 465629.

Mitra and Baldwin, (1997) Physiological changes and shelf life of mango (Mangifera indica) influenced by postharvest treatment. SAARC J. Agri., 15(2), 219-226.

Nair, S. and Singh, Z. (2003). Pre-storage ethrel dip reduces chilling injury, enhances respiration rate, ethylene production and improves fruit quality of 'Kensington Pride' mango. Journal of Food, Agriculture and Environment, 1(2), 9397.

Olivas, G. I. and Barbosa-Canovas G. V. (2005). Edible coatings for fresh-cut fruits. Critical Reviews in Food Science and Nutrition, 45, 657-670.

Oluwaseun AC, Kayode AA, Bolajoko FO, Bunmi AJ, Olagbaju AR.(2013) Effect of edible coatings of carboxy methyl cellulose and corn starch on cucumber stored at ambient temperature. Asian $J$ AgricBiol., 1(3), 133-140.

Radi M., Firouzi E., Akhavan H. and Amiri S., (2017). Effect of Gelatin-Based Edible
Coatings Incorporated with Aloevera and Black and Green Tea Extracts on the Shelf Life of Fresh-Cut Oranges. Journal of Food Quality, 9764650, 10 pages.

Rao Sudhakar, D.V. and Rao Gopalakrishna, K.P. (2008). Controlled atmosphere storage of mango cultivars 'Alphonso' and 'Banganapalli' to extend storage-life and maintain quality. Journal of Horticultural Science and Biotechnology, 83(3), 351-359.

Rowe T.D. (1940). Effect of fresh Aloe vera gel in the treatment of third-degree roentgen reactions on white rats. $J$ Am Pharm Assoc. 29, 348-50.

Sobral, P. J. A., Habitante, A. M. Q. B. (2001).Phase transitions of pigskin gelatin. Food Hydrocolloids, 15, 377-82.

Swain, S.N Biswal, Nanda P.K, and Nayak P.L (2004). Biodegradable soy based plastics: opportunities and challenges. Journal of polymer environment. 12 , 35-42.

Thompson, A. K. (2001). Controlled atmosphere storage of fruits and vegetables, UK CABI Publication, 278.

Tripathi, P. and Dubey, N. K. (2004). Exploitation of natural products as an alternative strategy to control postharvest fungal rotting of fruit and vegetables. Postharvest Biology and Technology, 32(3), 235-245.

Yehuala G.A and Emire A.S. (2013) Antimicrobial activity, physiochemical and mechanical properties of aloe (Aloe debrana) based packaging films. British journal of applied Science and Technology. 3(4), 1257-1275.

\section{How to cite this article:}

Praveen Kumar Dubey, Rama Nath Shukla, Gaurav Srivastava, Atul Anand Mishra and Ashutosh Pandey. 2019. Study on Quality Parameters and Storage Stability of Mango Coated with Developed Nanocomposite Edible Film. Int.J.Curr.Microbiol.App.Sci. 8(04): 2899-2935. doi: https://doi.org/10.20546/ijcmas.2019.804.339 